\title{
Composition in essential and non-essential elements of early stages of cephalopods and dietary effects on the elemental profiles of Octopus vulgaris paralarvae
}

\author{
Roger Villanueva ${ }^{\mathrm{a},{ }^{*}}$ and Paco Bustamante ${ }^{\mathrm{b}}$
}

\author{
a Institut de Ciències del Mar (CSIC), Passeig Marítim 37-49, E-08003 Barcelona, Spain \\ ${ }^{\mathrm{b}}$ Centre de recherche sur les Ecosystèmes Littoraux Anthropisés, UMR 6217 CNRS-IFREMER - \\ Université de La Rochelle, 22, Avenue Michel Crépeau, F-17042 La Rochelle, France \\ *: Corresponding author : roger@icm.csic.es
}

\begin{abstract}
:
During the present study, we aimed at providing a first look at the elemental composition of the early stages of cephalopods as an approach to their elemental requirements in culture. Essential and nonessential elemental profiles of the European cuttlefish Sepia officinalis, the European squid Loligo vulgaris and the common octopus Octopus vulgaris laboratory hatchlings and wild juveniles were analysed. In addition, for $O$. vulgaris we determined elemental profiles of mature ovary, eggs in different stages of development and followed possible effects of four dietary treatments during paralarval rearing, also analyzing elemental content of the live preys Artemia nauplii and Maja brachydactyla hatchling zoeae. Content was determined for essential (As, $\mathrm{Ca}, \mathrm{Cr}, \mathrm{Co}, \mathrm{Cu}, \mathrm{Fe}, \mathrm{K}, \mathrm{Mg}$, $\mathrm{Mn}, \mathrm{Na}, \mathrm{Ni}, \mathrm{P}, \mathrm{Rb}, \mathrm{S}, \mathrm{Sr}, \mathrm{Zn}$ ) and non-essential (Ag, Al, Ba, Cd, Hg, Pb) elements. The content in nonessential elements found in hatchlings and juveniles of the three species analyzed here seems to be far lower in comparison with subadult and adult stages of coastal cephalopods. In the octopus eggs, the non-essential element concentrations remained globally low compared to hatchlings and juveniles indicating the absorption of these elements along the ontogenetic development. The elemental composition of the octopus ovary and of the eggs, hatchlings and juveniles of the three cephalopod species analyzed here showed a high content in S. As expected, the calcified internal shell of the cuttlefish, rich in $\mathrm{Ca}$ and $\mathrm{Sr}$, originates the main difference between species. It is remarkable the richness in $\mathrm{Cu}$ of hatchling octopus, that may indicate a particular nutritional requirement for this element during the planktonic life. The reared octopus paralarvae feed on Artemia nauplii, a prey with relatively low $\mathrm{Cu}$ content, showed nearly half $\mathrm{Cu}$ content that the "natural" profile of octopus hatchlings or wild juveniles. This suggests a dietary effect and/or an indication of the poor physiological stage of the Artemia-fed paralarvae. At the present, the percentage of essential element absorption by food or seawater is unknown for cephalopods and should be determined in the future to understand their feeding requirements in culture.
\end{abstract}

Keywords: Biochemical composition; Eggs; Larvae; Sepia; Loligo; Octopus 


\section{Introduction}

Minerals are required for the maintenance of normal metabolic and physiological functions of living organisms. The main functions of essential elements in the animal body include the formation of skeletal structure, maintenance of colloidal systems, regulation of acid-base equilibrium and they are important components of hormones, enzymes and structural proteins (e.g. Simkiss, 1979; Williams, 1981; Lall, 2002). The present knowledge of the elemental composition of cephalopods mainly comes from subadult and adult forms and has focused on selected organs or body portions (see between others, Miramand and Bentley, 1992; Bustamante et al., 2000; Ichihashi et al., 2001a; Napoleao et al., 2005a). Most of theses studies have highlighted the very high ability of cephalopods to concentrate various toxic elements such as $\mathrm{Ag}$ or $\mathrm{Cd}$ (e.g. Martin and Flegal, 1975; Bustamante et al., 1998b, 2002a, 2004) and radionuclides such as ${ }^{241} \mathrm{Am},{ }^{60} \mathrm{Co}$, ${ }^{137} \mathrm{Cs},{ }^{210} \mathrm{Po}$ and ${ }^{237} \mathrm{Pu}$ (Suzuki et al., 1978, Guary et al., 1981, Smith et al., 1984, Yamada et al., 1999).

Cephalopods are carnivorous, active predators and the environmental induced toxic elements have been the subject of recent research regarding detoxification processes (Tanaka et al., 1983; Finger and Smith, 1987; Castillo et al., 1990; Castillo and Maita, 1991; Craig and Overnell, 2003; Bustamante et al., 2002b). However, the elemental requirements of this group of molluscs are poorly known and few studies have been done in relation with the elemental content of early stages of cephalopods and their possible role for the development of embryos and growth of paralarvae and juveniles (Decleir et al., 1970; Miyazaki et al., 2001). For example, it clearly appears that $\mathrm{Sr}$ is of ground importance for the shell and statolith development and thus normal swimming behaviour and survival of hatchling cephalopods (Hanlon et al., 1989).

Because cuttlefish are among the easier cephalopod species to rear, several experimental investigations have been carried out on the incorporation of trace elements by their eggs. These studies have shown the eggshell prevents the incorporation of some non-essential metals such as $\mathrm{Cd}, \mathrm{Pb}$, or $\mathrm{V}$ and of essential $\mathrm{Cu}$ and $\mathrm{Zn}$ as well (Paulij et al., 1990; Bustamante et al., 2002a; Miramand et al., 2006). But at the same time, other elements such as $\mathrm{Ag}$ and $\mathrm{Cs}$ can pass through the eggshell and become incorporated in embryonic tissues (Bustamante et al., 2004, 2006a). Element transport selectivity through the eggshell is apparently not determined by the metabolic needs of the embryo for essential elements, since the non-biologically essential element $\mathrm{Ag}$ is well known for its enhanced embryotoxicity (Calabrese et al., 1973; Martin et al., 1981; Warnau et al., 1996). By another hand, no information exist on the incorporation of elements by eggs in cephalopod species that lack eggshell, as in the incirrate octopods (in ex., Octopus vulgaris) which egg chorion is in direct contact with seawater. Overall, after the hatchling, accumulation of toxic elements shows two patterns with 1) metals such as Ag which is accumulated immediately since juveniles are in direct contact with seawater 2) metals such as $\mathrm{Cd}$ or $\mathrm{Pb}$ which are significantly incorporated only once the cephalopods start to feed (Miramand et al., 2006). After first feeding most part of the elements can be assumed to be incorporated from the diet and it is known that in juvenile cuttlefish Sepia officinalis the diet influences the elemental composition of the calcareous statoliths (Zumholz et al., 2006). However, the behaviour of most of essential elements remains poorly understood to date according to the bioaccumulation processes or to the nutritional needs of cephalopod paralarvae and juveniles.

Due to their rapid growth and market price, the culture of cephalopods has been an increasing area of interest (Walsh et al., 2002; García et al., 2004; Nabhitabhata et al., 2005; Sykes et al., 2006). However, the rearing of the delicate early stages seems to be the main bottleneck to develop the aquaculture of some species such as S. officinalis (Domingues et al., 2001, 2003; Koueta et al., 2002; Koueta and BoucaudCamou, 2003) and O. vulgaris (Itami et al., 1963; Villanueva, 1994, 1995; Carrasco et al., 2003; Iglesias et al., 2004; Okumura et al., 2005). The artificial feeding of the early stages of cephalopods is an unresolved problem and to the present only cultures at experimental scale using natural prey has been successful. Aside from the problems related to food size and quantity, there seem to be other problems associated with food quality. Previous studies on the biochemical composition of the early stages of cephalopods have been developed as first approaches to determine their feeding requirements for lipids and amino acids, trying to design possible co-feeding techniques using Artemia and microdiets suitable for the paralarval feeding behaviour (Villanueva et al., 1995, 1996, 2004; Rosenlund et al., 1997; Hernández-García et al., 2000; Navarro and Villanueva, 2000, 2003). The present work follows this research topic aiming at taking a first insight on the elemental requirements of the paralarval and juvenile stages of cephalopods in culture.

First, we determined the elemental composition of laboratory hatchlings and wild juveniles of three shallow water cephalopod species that represent the main cephalopod orders, all of them of high commercial interest: the European cuttlefish $\underline{\mathrm{S}}$. officinalis, the European squid Loligo vulgaris and the common octopus, $\underline{O}$. vulgaris. Second, for $\underline{O}$. vulgaris we determined the same elemental profiles in mature ovary, eggs in different stages of development, hatchlings fasted during 4 days, paralarvae reared to 20 days with four dietary treatments, and the Artemia nauplii used as food during these experiments. In addition, we analyzed hatchling zoeae of the spider crab Maja brachydactyla, a prey that has been successfully used previously as 


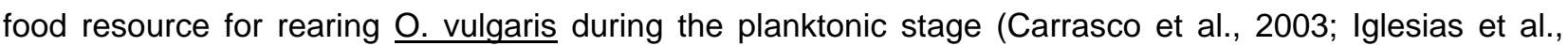
2004).

Following Mason and Jenkins (1995), we divided here the analyzed elements as essential elements (As, $\mathrm{Ca}, \mathrm{Cr}, \mathrm{Co}, \mathrm{Cu}, \mathrm{Fe}, \mathrm{K}, \mathrm{Mg}, \mathrm{Mn}, \mathrm{Na}, \mathrm{Ni}, \mathrm{P}, \mathrm{Rb}, \mathrm{S}, \mathrm{Sr}, \mathrm{Zn}$ ) and non-essential elements (Ag, Al, Ba, Cd, Hg, $\mathrm{Pb}$ ). Even $\mathrm{Sr}$ is generally reported as a non essential element for biota, it is essential for cephalopods according to Hanlon et al. (1989) (see above). The knowledge about the essential character and function of each element in cephalopods is poorly known and this classification may change according with future research.

\section{Material and Methods}

\subsection{Collection of material}

\subsubsection{Cephalopod hatchlings and wild juveniles}

Specimens analyzed here were used also to obtain their amino acid composition in a previous published study (Villanueva et al., 2004) where detailed information on the collection of material is indicated. In short, egg masses of Sepia officinalis and Loligo vulgaris were collected off Barcelona (NW Mediterranean) and egg masses of Octopus vulgaris were obtained from a broodstock maintained in the Institut de Ciències del Mar (ICM), Barcelona. Healthy individuals of all three species were preserved during the first $24 \mathrm{~h}$ after hatching in the laboratory. The samples were collected using a hand net, washed in tap water, then placed on blotting paper to remove the excess water, weighed on a microbalance, frozen at $-80^{\circ} \mathrm{C}$ and freeze-dried overnight. The dry weight was obtained from the freeze dried samples, which were then stored again at $80^{\circ} \mathrm{C}$ for subsequent elemental analysis (see below). To determine wild juvenile elemental profiles, $6 \mathrm{~S}$. officinalis wild juveniles (25.9-103.8 $\mathrm{g}$ wet weight) collected from the artisanal fishery off Cambrils (Tarragona, NW Mediterranean); $5 \mathrm{~L}$. vulgaris juveniles (2.0-2.8 g wet weight) collected from the local trawl fishery off Barcelona (NW Mediterranean) and 5 benthic $\underline{0}$. vulgaris juveniles (3.5-14.2 $\mathrm{g}$ wet weight) captured from the wild by scuba diving off L'Estartit (NW Mediterranean) were analyzed. All juveniles were weighed fresh and frozen at $-80^{\circ} \mathrm{C}$ upon arrival in the laboratory. All wild juveniles were freeze-dried, with

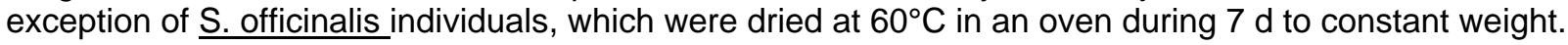

\subsubsection{Rearing experiments of Octopus vulgaris paralarvae}

Specimens analyzed here belong to the same culture experiments reported also in Villanueva et al. (2004) were detailed information on rearing methods can be found. Four experimental treatments were used (see below) and each treatment was conducted in quadruplicate. Paralarvae were reared for $30 \mathrm{~d}$ using cylindrical 25-I volume PVC tanks at mean temperature of $20.4{ }^{\circ} \mathrm{C}$ (range $19.2-21.1^{\circ} \mathrm{C}$ ). In all experiments, on day 20 , all individuals in each rearing tank were counted and transferred to an identical clean tank. The percentage survival $(S)$ was calculated as $S=100 S \cdot(I-B)^{-1}$, where $S$ was the number of surviving individuals on day $x$, I was the initial number of individuals in the culture, and $B$ was the total number of individuals killed for sampling purposes to day $x$. On day 20, to determine growth and for subsequent analysis (see below), 6 samples of 20 paralarvae each were collected from each rearing experiment. Paralarval samples were collected $2 \mathrm{~h}$ after the first daily food addition (see below), washed in tap water, placed over a plastic mesh on blotting paper to remove excess water, stored in Eppendorf tubes, weighed, frozen at $-80^{\circ} \mathrm{C}$ and freeze-dried overnight. The dry weight was obtained from the freezedried paralarvae, which were stored again at $-80^{\circ} \mathrm{C}$ for subsequent elemental analysis (see below).

\subsubsection{Feeding treatments of Octopus vulgaris paralarvae}

All treatments were fed enriched Artemia nauplii (AF, INVE Aquaculture) $450 \mu \mathrm{m}$ in length, which were provided from day 0 to day 20 at a ration of 6-7 nauplii $\mathrm{ml}^{-1} \mathrm{~d}^{-1}$. Artemia nauplii were enriched in seawater for $24 \mathrm{~h}$ at $28^{\circ} \mathrm{C}$ with one of the following enrichment diets: a) Diet SS: DC Super Selco (INVE) $0.6 \mathrm{~g} \mathrm{I}^{-1}$, and, (b) Diet MET: DC Super Selco $0.6 \mathrm{~g} \mathrm{l}^{-1}$ and $0.8 \mathrm{~g} \mathrm{l}^{-1}$ of L-methionine (Sigma Products). To test the influence of the presence of amino acids in seawater, essential L-amino acids in crystalline form (Sigma Products) were added to the rearing tanks (see Villanueva et al., 2004 for details) and four treatments were tested, 1) Control group: paralarvae were fed Artemia nauplii enriched with Diet SS; 2) MET group: paralarvae were fed Artemia nauplii enriched with Diet MET; 3) AA group: paralarvae were fed Artemia nauplii enriched with Diet SS and they also received a daily amino acids solution in the rearing tank, and, 4) METAA group: paralarvae were fed Artemia nauplii enriched with Diet MET and they also received a daily amino acids solution in the rearing tank. An unfed group was also maintained from the hatchling stage to day 4. 


\subsubsection{Paralarval preys}

The elemental compositions of Artemia nauplii from the Diet SS and Diet MET groups, as well as the elemental composition of recently hatched zoeae of spider crab Maja brachydactyla were analysed. These zoeae (not used as food during the present study) have been used previously with success as a food resource for rearing Octopus vulgaris (Carrasco et al., 2003; Iglesias et al., 2004) during the first two months of paralarval life. Samples were collected and preserved as described for the cephalopod paralarvae.

\subsubsection{Mature ovary and eggs of Octopus vulgaris}

Ovary samples were obtained from a wild mature female, 2900-g total fresh weight, collected off Barcelona. Eggs of stage I-II and X-XII (Naef, 1928) were collected from egg masses obtained in the laboratory.

\section{2. Analytical}

\subsubsection{Elemental profiles}

Elemental analyses were carried out at the Serveis Cientificotècnics, Universitat de Barcelona. All elemental analyses were made from three $25 \mathrm{mg}$ dry weight aliquotes. Homogenized dry samples were digested with $1 \mathrm{ml} \mathrm{HNO}$ and $1 \mathrm{ml} \mathrm{H}_{2} \mathrm{O}_{2}$ ("Baker Instra") in $60 \mathrm{ml}$ teflon reactors (Savillex, catalog number $561 \mathrm{R} 2$, Techmate, UK) overnight at $90{ }^{\circ} \mathrm{C}$. After digestion, $15 \mathrm{ml}$ deionized $\mathrm{H}_{2} \mathrm{O}$ (Milli-Q quality), was added and final weight obtained. Density of the sample was calculated by weight of $5 \mathrm{ml}$ of digested solution. Samples were digested by triplicate with 8 blanks in each batch of analysis.

Determination of $\mathrm{Ca}, \mathrm{Fe}, \mathrm{K}, \mathrm{Mg}, \mathrm{Na}, \mathrm{P}$ and $\mathrm{S}$ were obtained by inductively coupled plasma (ICP-AES) using a Perkin Elmer Optim $3200 \mathrm{RL}$ multichannel analyzer calibrated with 5 standards in $5 \% \mathrm{HNO}_{3}$ .Digested samples were analyzed without dilution. Determination of $\mathrm{Ag}, \mathrm{Al}, \mathrm{As}, \mathrm{Ba}, \mathrm{Cd}, \mathrm{Co}, \mathrm{Cr}, \mathrm{Cu}, \mathrm{Hg}$, $\mathrm{Mn}, \mathrm{Ni}, \mathrm{Pb}, \mathrm{Rb}, \mathrm{Sr}$, and $\mathrm{Zn}$ were obtained by inductively coupled plasma mass spectrometry (ICP-MS) using a Perkin Elmer ELAN 6000 analyzer, calibrated with 5 standards in $1 \% \mathrm{HNO}_{3}$. Rhodium was used as internal standard. Digested samples were analyzed without dilution, with Rh addition by flow injection analysis system.

Reference materials from the Community Bureau of Reference (BCR) of the Commission of the European Communities, Plankton CRM 414 and Cod Muscle CRM 422, were treated and analysed in the same way. Results for the standard reference materials were in good agreement with certified values and the mean recovery of all elements was of $99 \pm 15 \%$ (range: $73-128 \%$ ).

\subsection{Data treatment}

Mean values (after arcsinus-transformation for survival data) were compared by the Student t-test and analysis of variance, followed by the Tukey-Kramer HSD test. Differences were considered significant when $\mathrm{P}<0.05$. Data were assessed using the JMP statistical package.

\section{Results}

Elemental composition of Sepia officinalis, Loligo vulgaris and Octopus vulgaris hatchlings are shown in Table 1. Sulphur, $\mathrm{Na}, \mathrm{K}, \mathrm{P}$, and $\mathrm{Mg}$ were the main elements present in the three species. The calcified, large internal shell of the cuttlefish originates the main structural difference among species. As a result, levels of $\mathrm{Ca}$ in $\mathrm{S}$. officinalis hatchlings reached more that 5 times that of the other species. Consistently, $\mathrm{Sr}$ also showed the higher content as this element has a close behaviour as $\mathrm{Ca}$. In $\underline{\mathrm{O}}$. vulgaris, levels of $\mathrm{Ag}, \mathrm{Cu}, \mathrm{Mn}, \mathrm{Ni}$ and $\mathrm{Zn}$ were relatively high, reaching $\mathrm{Ag}$ and $\mathrm{Cu} 5$ and 3 times that recorded in other species, respectively. Some differences in other elements were observed and only $\mathrm{Fe}, \mathrm{Hg}$ and $\mathrm{Pb}$ contents were found fairly constant in hatchlings of the three species.

Elemental composition in juvenile wild individuals of the three species is showed in Table 2. In comparison with hatchlings, wild juveniles of the three species increased their content in $\mathrm{Ba}, \mathrm{Cd}$, and $\mathrm{Na}$ and decreased in $\mathrm{K}$ and $\mathrm{P}$. A positive correlation between juvenile dry weight and elemental content was found for $\mathrm{Cu}, \mathrm{Sr}$ and $\mathrm{Zn}$ in $\underline{\mathrm{S}}$. officinalis; $\mathrm{Al}, \mathrm{Fe}, \mathrm{K}$ and $\mathrm{Rb}$ in $\underline{\mathrm{L}}$. vulgaris; and $\mathrm{P}$ and $\mathrm{S}$ in $\underline{\mathrm{O} \text {. vulgaris. }}$. 
In $\underline{\mathrm{O}}$. vulgaris, a notable increase in $\mathrm{Ag}, \mathrm{Ca}, \mathrm{Cu}, \mathrm{K}, \mathrm{Mg}, \mathrm{Na}$ and $\mathrm{Sr}$ were observed when comparing the mature ovary with the spawned eggs. These elements increased again in the hatchlings, with exception of the $\mathrm{Ag}$ (Table 3). In comparison with recently spawned eggs, the developing $\underline{O}$. vulgaris eggs have higher concentrations in all the major essential elements, most of the minor essential elements and also some of the non-essentials as $\mathrm{Ag}$ and $\mathrm{Pb}$ (Table 3). After $4 \mathrm{~d}$ of fasting, hatchlings lost $28 \%$ of their dry weight, decreasing their content in $\mathrm{Cu}, \mathrm{K}, \mathrm{Mn}, \mathrm{P}$ and $\mathrm{Rb}$, and increasing their levels of $\mathrm{Ag}, \mathrm{As}, \mathrm{Ca}, \mathrm{Fe}, \mathrm{Sr}$ and $\mathrm{Zn}$ (Table 3).

In $\mathrm{O}$. vulgaris paralarvae after $20 \mathrm{~d}$ of rearing, no significant differences were found for $\mathrm{Ag}, \mathrm{Ba}, \mathrm{Ca}, \mathrm{Co}$, $\mathrm{Fe}, \mathrm{K}, \mathrm{Rb}, \mathrm{Sr}$ and $\mathrm{Zn}$ contents between the four feeding treatments. Groups that reached the low survival (Control and MET groups, survival of 13-17\%) have lower levels of $\mathrm{Mg}$ and $\mathrm{S}$ than groups with higher survival (AA and METAA groups, survival of 41-54\%) (Table 4). Arsenic and $\mathrm{Cu}$ reach also the higher levels on the group with best survival (METAA group, Table 4); however, all reared individuals decrease their $\mathrm{Cu}$ levels to nearly half percent of the hatchling $\mathrm{Cu}$ content, decreasing also As. In contrast, $\mathrm{Zn}$ increased notably from the hatchling levels as $\mathrm{Ag}, \mathrm{Ba}, \mathrm{Cd}$, and $\mathrm{Pb}$. These differences were maintained when comparing with the wild juveniles. In this way, the elemental profile of the reared paralarvae from the Control group, in comparison with the "natural" profile of the hatchlings and wild juveniles, showed low content in As, Cu, Mg and S, and high content in Ag and Zn (Figs. 1, 2 and 3).

Elemental composition of the preys, Artemia and Maja zoeae, are shown in Table 5. The main element in both species was $\mathrm{Na}$, with higher content in the spider crab zoeae. Elemental profiles of both preys differ notably. Concentration of $\mathrm{Ca}$ and $\mathrm{Sr}$ in Maja were nearly 40 times higher than that of Artemia, and Cu and Mg were also 8 and 5 times respectively higher in Maja. As expected, enrichment of Artemia by methionine (Artemia MET nauplii) resulted in a higher $S$ content in these nauplii due to the $S$ richness of this amino acid. However, these enriched Artemia do not reach the $S$ content of the Maja zoeae. By another hand, Artemia nauplii were rich in Fe and Ni. No differences between Artemia and Maja were found in $\mathrm{Cd}, \mathrm{K}, \mathrm{Mn}, \mathrm{P}$ and $\mathrm{Zn}$ content.

\section{Discussion}

\subsection{Elemental content profiles of early stages of cephalopods}

First investigations about trace elements in cephalopods have focused on essential elements, particularly on $\mathrm{Cu}$ because of its role in the haemocyanin (Ghiretti-Magaldi et al., 1958; Rocca, 1969; Nardi et al., 1971; Nardi and Steinberg, 1974) and to the interactions with non-essential elements (e.g., Martin and Flegal, 1975; Miramand and Guary, 1980; Smith et al., 1984; Finger and Smith, 1987; Miramand and Bentley, 1992). Most of these studies concerned a single organ, mainly the digestive gland known to play a major role in the energetic metabolism of cephalopods, and also on the branchial hearts and their appendages which are involved in the excretion processes. These different works although limited to a narrow number of cephalopod species have clearly shown that these organs are deeply involved in the metabolism of $\mathrm{Ag}, \mathrm{Cd}, \mathrm{Cu}, \mathrm{Hg},{ }^{210} \mathrm{Po}$ and $\mathrm{Zn}$ for the digestive gland and of ${ }^{241} \mathrm{Am}, \mathrm{Co}, \mathrm{Fe}, \mathrm{V}$ and ${ }^{237} \mathrm{Pu}$ for the branchial hearts (Renzoni et al., 1973; Nardi and Steinberg, 1974; Martin and Flegal ,1975; Miramand and Guary, 1980; Guary et al., 1981; Smith et al., 1984; Finger and Smith, 1987; Miramand and Bentley, 1992; Bustamante et al. 2006b). Conversely, a limited number of studies have determined the concentrations in reproductive tissues as ovary and testis, and in the eggs (e.g. Bustamante et al., 1998c; Gerpe et al., 2000, Craig and Overnell, 2003; Seixas et al., 2005, Miramand et al., 2006). These results were obtained with cephalopod collected from the field focusing on the levels of non essential metals to infer their potentially toxic effects on the reproductive tissues and/or on the embryos. However, to the best of our knowledge the metabolic requirements of trace elements have not been studied to date in cephalopods.

The elemental composition of the octopus ovary and of the eggs, hatchlings and juveniles of the three cephalopod species analyzed here showed a high content in $\mathrm{S}$. This high level can be expected because of the protein-rich, muscular body that characterizes cephalopods (Lee, 1994; Villanueva et al., 2004). For example, muscle S content reached up $75 \%$ of the total whole body burden of the purpleback flying squid Sthenoteuthis oualaniensis (Ichihashi et al., 2001a). The S concentrations recorded in eggs, hatchlings and juvenile of Sepia officinalis, Loligo vulgaris and Octopus vulgaris globally fall within the $S$ concentrations reported for the muscle of the squid Todarodes pacificus (Median $=4700 \mu \mathrm{g} \cdot \mathrm{g}^{-1}$ wet weight) and in the ovary of the squid S. oualaniensis (3400 $\mu \mathrm{g} \cdot \mathrm{g}^{-1}$ wet weight) (Ichihashi et al., 2001ab). Sulphur is also abundant in the composition of hard structures of cephalopods such as the chitin of beaks (Hunt and Nixon, 1981), the vestigial shell of adult Octopus vulgaris (Napoleao et al., 2005b), the gladius 
of adult S. oualaniensis (Ichihashi et al. 2001a), and the eggshell of the cirrate octopods (Villanueva, 1992).

The calcified shell of the cuttlefish originates the main structural and compositional difference among the species studied resulting in levels of $\mathrm{Ca}$ for $\mathrm{S}$. officinalis more that five times that other hatchlings, in addition to remarkable high levels of Sr. In S. officinalis, the shell represents around 6\% of the dry weight at hatching (Villanueva et al., 2004) and Ca and Sr are the most abundant elements in the calcified shell of adult cuttlefish $\underline{S}$. latimanus (Ikeda et al., 1999) as well as important components of the ink of adult $\mathrm{S}$. officinalis and S. oualaniensis (Sarzanini et al., 1992; Ichihashi et al., 2001a). The relatively high Ca and Sr content of the ink of cephalopods have been attributed to its richness in melanin (Sarzanini et al., 1992).

The embryonic development of nautiluses, cuttlefishes, squids and cirrate octopods occur in an eggs protected by a capsule which thickness varies according to the species. Inside the egg of cuttlefish, concentrations of non-essential elements (in ex. $\mathrm{Ag}, \mathrm{Cd}, \mathrm{Pb}$ ) remains very low which suggest a limited transfer of these metals 1) towards the gonad during the maturation process and 2) through the eggshell during the embryonic development (Miramand and Bentley, 1992; Bustamante et al., 2002a, 2004; Miramand et al., 2006). In comparison, concentrations of essential trace elements are relatively elevated in the ovary, which is probably related to the high concentrations of metalloproteins such as $\mathrm{Zn}$-rich proteins in this tissue (Gerpe et al., 2000). In the eggs, a very low percentage of $\mathrm{Cu}$ is under soluble form in Loliginid squids, suggesting the binding to a particular compound acting as a Cu reserve for the embryonic development (Craig and Overnell, 2003). Generally low coefficients of variation for both $\mathrm{Cu}$

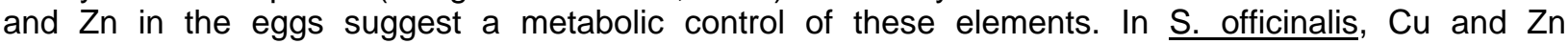
concentrations in the hatchlings are close to those measured in the vitellus, probably constituting virtually the unique source of these elements for the embryos (Miramand et al., 2006).

By another hand, eggs of incirrate octopods (in ex., Octopus vulgaris) lacks eggshell and the chorion is in direct contact with the seawater. Present results showed that in comparison with recently spawned eggs, the developing $\mathrm{O}$. vulgaris eggs have higher concentrations for most of the essential elements and also for some of the non-essentials (i.e., $\mathrm{Ag}$ and $\mathrm{Pb}$ ). This difference with encased eggs could be due to the absorption of these elements from the seawater during the embryonic development in $\underline{O}$. vulgaris.

Differences on the elemental composition during the ontogenetic development have been observed in cephalopods depending on the considered element and on the species (Bustamante, 1998a). The content in non-essential elements found in the three species analyzed here seems to be lower in comparison with subadult and adult stages of coastal cephalopods (Miramand and Guary, 1980; Miramand and Bentley, 1992; Seixas et al., 2005; Miramand et al., 2006). By another hand, levels of some essential elements are found in higher concentrations in the digestive gland of juvenile that adult squids S. oualaniensis for $\mathrm{Ca}, \mathrm{Cr}, \mathrm{Na}, \mathrm{Mg}$ and $\mathrm{Sr}$, and Loligo forbesi for $\mathrm{Cd}$, which may attributable to diet ontogenetic changes (Ichihashi et al., 2001a; Stowasser et al., 2005).

\subsection{Elemental requirements for early stages of cephalopods: an approach}

Cephalopods are carnivorous, active predators and because they have very high feeding rates, most part of the elements can be assumed to be incorporated by the diet. However, absorption also takes place from seawater, as it occurs for instance for Ag (Bustamante et al., 2004; Miramand et al., 2006) and also probably for $\mathrm{Hg}$ (Bustamante et al., 2006b). In addition to an osmotic uptake through the gills and the body surface, in cephalopods seawater is taken into the gut by the mouth and rectal pumping and the digestive gland appendages are the principal site of fluid uptake, regulating ion balance (Wells and Wells, 1989). To the best of our knowledge, no data on the respective proportions of the elements incorporated from food and seawater has been published to date for cephalopods. Fishes can take up significant amounts of $\mathrm{Ca}, \mathrm{K}, \mathrm{Mg}$ and $\mathrm{Na}$ from seawater (Lall, 2002); however, feed is the major source of essential elements such as $\mathrm{Cu}, \mathrm{Fe}, \mathrm{Mn}, \mathrm{P}$ and $\mathrm{Zn}$, which have low concentrations in seawater (Watanabe et al., 1997). A similar relationship can also be expected for cephalopods.

Present results for $\mathrm{S}$. officinalis showed that $\mathrm{Ca}$ and $\mathrm{Sr}$ contents in wild juveniles increased more than three times the hatchling level, exceeding S concentrations. Seawater contains an appreciable amount of dissolved $\mathrm{Ca}$ that can be a source of this element for cephalopods. However, no studies on the Ca requirements have been done for this group of carnivorous molluscs. In other molluscs as in juvenile abalone, adequate $\mathrm{Ca}$ is probably obtained from the surrounding water and high levels of supplemental $\mathrm{Ca}$ did not significantly increase the tissue Ca content (Tan et al., 2001). In fish, the utilization of Ca from seawater varies according to the species. Calcium absorption from seawater can be sufficient to maintain 
stable the tissue Ca levels but do not provide enough Ca for normal fish growth. With a reduced Ca supply from the diet of some fish species, it results a significantly poorer growth and feed efficiency (Hossain and Furuichi, 2000). Under experimental conditions, the shell growth rate of low-feeding, young

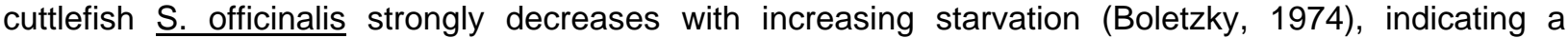
possible feed requirement independent of a $\mathrm{Ca}$ intake from seawater. In the case of Sr, this element is incorporated into the squid and cuttlefish statolith from the diet (Hurley et al., 1985; Zumholz et al., 2006) and from seawater (Hanlon et al., 1989). The calcified structures of cephalopods such as shell and statoliths require this element for normal embryonic development and survival. Egg incubations in artificial seawater without Sr produces abnormal hatchlings in the three species studied here and only normal development of the aragonite statoliths were obtained when Sr levels in seawater reach $8 \mathrm{mg} \mathrm{l}^{-1}$ (Hanlon et al., 1989).

An interesting element in cephalopods is $\mathrm{Cu}$. This metal is required in large concentrations in cephalopods as it works as a respiratory pigment in hemocyanin which represents $98 \%$ of their blood proteins (Ghiretti, 1966; D'Aniello et al., 1986). From the literature, levels of Cu are reported for the gills, branchial hearts, digestive gland and muscle of adult cephalopods, including Octopus vulgaris (for recent literature review see Table 6 of Napoleao et al., 2005a). The $\mathrm{Cu}$ concentrations observed here in $\underline{\mathrm{O}}$. vulgaris hatchlings are similar to that reported for the gills of adults of the same species. The Cu abundance in the adult octopus gills may reflects the presence of haemocyanin, the dioxygen carrier $\mathrm{Cu}$ protein typical of molluscs and crustaceans (Taylor and Anstiss, 1999). However, these levels of Cu for the octopus hatchling, as a whole animal, seem to be relatively high compared to the adults. The richness in $\mathrm{Cu}$ of planktonic octopus may indicate a particular high nutritional requirement for this element. In decapod crustaceans, enzymatic requirements have been estimated to be around $26 \mu \mathrm{g} \cdot \mathrm{g}^{-1}$ of $\mathrm{Cu}$ and the total metabolic requirements (enzymes and haemocyanin) to be around $83 \mu \mathrm{g} \cdot \mathrm{g}^{-1}$ (Rainbow 1988, Zauke and Petri, 1993). These estimated requirements for adult octopus are similar, reaching levels of 26 and $92 \mu \mathrm{g} \cdot \mathrm{g}^{-1}$ of $\mathrm{Cu}$, respectively (White and Rainbow, 1985). Crustaceans constitute the main prey of many cephalopod species, particularly during paralarval and juvenile stages (Vecchione, 1991; Passarella and Hopkins, 1991) and crabs are the preferred prey of adult octopus in the wild (Nixon, 1987), between other reasons, probably because they are rich in $\mathrm{Cu}, \mathrm{Zn}$, cholesterol and n-3 fatty acids (King et al., 1990; Skongberg and Perkins, 2002). García García and Cerezo Valverde (2006) reported the optimal proportion of crabs in a fish + crab diet for ongrowing subadult $\underline{O}$. vulgaris, noted that no cannibalism are reported when the minimum levels of crabs are maintained in the diet and pointed out a possible $\mathrm{Cu}$ dietary influence. In the same way, mortality associated with low Cu content diets has been also signalled

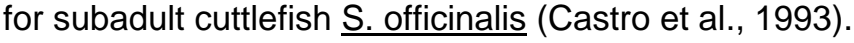

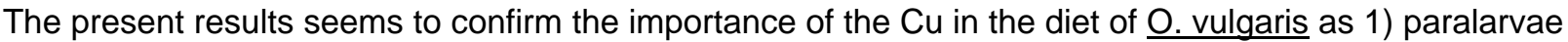
of $20 \mathrm{~d}$ old feed on an Artemia diet showed significantly less Cu content that the "natural" Cu profile of hatchlings or wild juveniles, and 2) the paralarval group with poor survival (control) recorded the lower $\mathrm{Cu}$ content in comparison with the higher levels recorded for the group with best survival. In addition, prey composition analyzed here showed that Artemia nauplii have $\mathrm{Cu}$ levels 20 times lower that $\mathrm{O}$. vulgaris hatchlings and 8 times lower that Maja brachydactyla zoeae, a prey used previously with

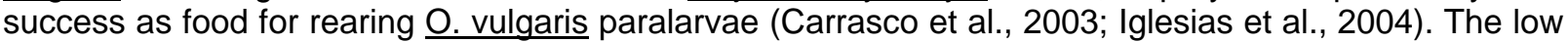

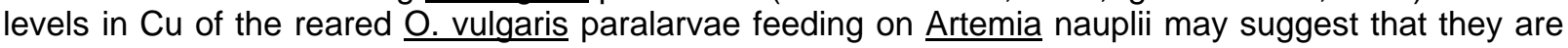
resulting from the low $\mathrm{Cu}$ content of Artemia and/or resulting from the poor physiological stage of the octopus paralarvae. Conclusions on this subject need further research, however, the Cu content of the M. brachydactyla zoeae $\left(73 \mu \mathrm{g} \mathrm{g}^{-1}\right.$, see Table 5) may be considered as an optimal estimation of the Cu feeding requirement for $\underline{O}$. vulgaris paralarvae under culture conditions. The deficient nutrient

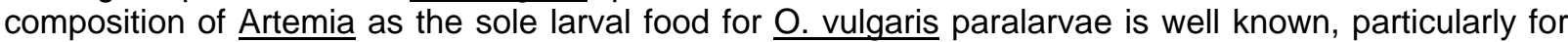
lipid requirements (Navarro and Villanueva, 2000, 2003; Villanueva et al., 2002). However, in addition to other nutritional requirements, mainly from lipidic origin, $\mathrm{Cu}$ seems to be an important element on the paralarval octopus diet. Future studies are necessary to quantify these Cu dietary needs may testing a possible lipid + bioavailable $\mathrm{Cu}$ enriched Artemia suitable for paralarval octopus culture. To this respect, it should be borne in mind that $\mathrm{Cu}$ uptake by Artemia is influenced by $\mathrm{pH}$ and temperature (Blust et al., 1988; 1994).

In samples with low levels of $\mathrm{Cu}$ (fasted or reared paralarvae), Zn content increase notably compared to the hatchling or juvenile wild octopus Zn contents, that showed higher level of Cu. Similarly to Cd, Fe and Mo, $\mathrm{Zn}$ can act as a metabolic antagonist of $\mathrm{Cu}$ because of their similar nature of the valence shell hybrids and they compete for binding sites on proteins responsible for mineral absorption and/or synthesis of metalloenzymes (Watanabe et al., 1997; Lall, 2002). However, the details of such mechanisms in cephalopods are little known (Craig and Overnell, 2003). In adult octopus, enzymatic requirements have been estimated to be around $35 \mu \mathrm{g} \cdot \mathrm{g}^{-1}$ of $\mathrm{Zn}$ and the total metabolic requirements 
(enzymes and haemocyanin) to be around $81 \mu \mathrm{g} \cdot \mathrm{g}^{-1}$ (White and Rainbow, 1985). Zn is involved in numerous protein functions such as the carbonic anhydrase and is efficiently absorbed and strongly retained in $\underline{S}$. officinalis both from the food and seawater pathways. In this species, the assimilation efficiency $(A E)$ of $Z n$ from food was higher for juveniles $(A E=63 \%)$ than for adults ( $A E=41 \%)$ which may result from higher metabolic requirements in juveniles (Bustamante et al., 2002).

In the reared $\mathrm{O}$. vulgaris individuals, $\mathrm{As}, \mathrm{Mg}$ and $\mathrm{S}$ also exhibited lower content in comparison with the "natural" profile of the hatchlings and wild juveniles (Figs. 1 and 2). In addition, $\mathrm{Mg}$ and $\mathrm{S}$ have lower contents on the reared groups with poor survival. The reduction of $S$ concentrations may be due to a loss of muscle material and/or to the use of muscular protein to allow the organism at surviving. In fact, direct mobilization of muscle protein provides metabolic energy during periods of starvation in adult octopus (O'Dor et al., 1984). Magnesium is an essential cofactor in many enzymatic reactions in intermediary metabolism, however, the $\mathrm{Mg}$ requirements for cephalopods are unknown. The high $\mathrm{Mg}$ content in seawater makes not necessary to supplement diets of seawater fishes as they obtain $\mathrm{Mg}$ by drinking (Lall, 2002) and a similar way can be expected for cephalopods. The content of As in the arms of adult 0 . vulgaris was supposed to be mainly under the non-toxic form, i.e., arsenobetaine (Seixas et al., 2005). The role of this element in early stages of cephalopods is also unknown.

\subsection{Conclusion}

Comparison of element concentrations in the eggs of cuttlefish, squid and octopus show that cephalopods may have developed different strategies regarding elemental requirements of the embryos with 1) eggs protected by an eggshell preventing from the incorporation of waterborne elements whatever they are essential or not 2) eggs with a chorion in direct contact with seawater, allowing the incorporation of various dissolved elements. However, in both cases, non-essential element concentrations remained globally low compared to juveniles or adults. On another hand, the present results on the elemental composition and both natural and artificial food strongly suggest that cephalopod paralarvae and juveniles must require a food rich in $\mathrm{Cu}$. This is particularly clear for the octopus paralarvae and is probably related with the haemocyanin requirements for oxygen transport. In addition, the $\mathrm{Ca}$ requirements of the cuttlefish are also particularly high due to the well developed calcareous internal shell. At the present, the knowledge on the proportion of essential element incorporation from seawater or by food is lacking in this group of carnivorous molluscs and new research is urgently needed to understand the elemental requirements of cephalopods in culture.

\section{Acknowledgements}

We appreciate the technical assistance of J. Riba and M. Baeta during the rearing experiences. Elemental analyses were carried out at the Serveis Cientificotècnics, Universitat de Barcelona and we appreciate the technical assistance and advices of E. Pelfort and G. Lacort during the course of the work. This study was funded by the Centre de Referència de Recerca i Desenvolupament en Aqüicultura, CIRIT, Generalitat de Catalunya; the Planes Nacionales JACUMAR, Ministerio de Agricultura, Pesca y Alimentación, Spain; and by the Commission of the European Communities within the framework of the EU Concerted Action CEPHSTOCK (QLRT-2001-00962). RV was supported by the Programa para Movilidad de Investigadores of the Spanish Ministry of Science. 


\section{References}

Blust, R., Van der Linden, A., Verheyen, E., Decleir, W., 1988. Effect of pH on the biological availability of cooper to the brine shrimp Artemia franciscana. Mar. Biol. 98, 31-38.

Blust, R., Ginneken L.v., Decleir, W., 1994. Effect of temperature on the uptake of cooper by the brine shrimp, Artemia franciscana. Aquat. Toxicol. 30, 343-356.

Boletzky, S. v., 1974. Effets de la sous-nutrition prolongée sur le développment de la coquille de Sepia officinalis L. (Mollusca, Cephalopoda). Bull. Soc. Zool. Fr. 99, 667-673.

Bustamante, P., 1998a. Etude des processus de bioaccumulation et de détoxication d'éléments traces (métaux lourds et Terres Rares) chez les mollusques céphalopodes et bivalves pectinidés. Implication de leur biodisponibilité pour le transfert vers les prédateurs. PhD thesis, University of La Rochelle, 290 p.

Bustamante, P., Caurant, F., Fowler, S. W., Miramand, P., 1998b. Cephalopods as a vector for the transfer of cadmium to top marine predators in the North East Atlantic Ocean. Sci. Tot. Environ. 220, 7180.

Bustamante, P., Cherel, Y., Caurant, F., Miramand, P., 1998c. Cadmium, copper and zinc in octopuses from Kerguelen Islands, Southern Indian Ocean. Polar Biol. 19,264-271.

Bustamante P, Grigioni S, Boucher-Rodoni, R., Caurant, F., Miramand, P., 2000. Bioaccumulation of 12 trace elements in the tissues of the nautilus Nautilus macromphalus from New-Caledonia. Mar. Pollut. Bull. 40 (8), 688-696.

Bustamante, P., Teyssié J.L., Fowler, S. W., Cotret, O., Danis, B., Miramand, P., Warnau, M., 2002a. Biokinetics of zinc and cadmium accumulation and depuration at different stages in the life cycle of the cuttlefish Sepia officinalis. Mar. Ecol. Prog. Ser. 231, 167-177.

Bustamante, P., Cosson, R. P., Gallien, I., Caurant, F., Miramand, P., 2002b. Cadmium detoxification processes in the digestive gland of cephalopods in relation to accumulated cadmium concentrations. Mar. Environ. Res. 53, 227-241.

Bustamante, P., Teyssié, J-L., Danis, B., Fowler, S. W., Miramand, P., Cotret, O., Warnau, M., 2004. Uptake, transfer and distribution of silver and cobalt in tissues of the common cuttlefish Sepia officinalis at different stages of its life cycle. Mar. Ecol. Prog. Ser. 269, 185-195.

Bustamante, P., Teyssié, J-L., Fowler, S. W., Warnau, M., 2006a. Contrasting bioaccumulation and transport behaviour of two artificial radionuclides $\left({ }^{241} \mathrm{Am}\right.$ and $\left.{ }^{134} \mathrm{Cs}\right)$ in cuttlefish eggshell. Vie Milieu 56 , 153-156.

Bustamante, P., Lahaye, V., Durnez, C., Churlaud, C., Caurant, F., 2006b. Total and organic Hg concentrations in cephalopods from the North East Atlantic waters: influence of geographical origin and feeding ecology. Sci. Tot. Environ. (in press).

Calabrese, A., Collier, R. S., Nelson, D. A., Mac Innes, J. R., 1973. The toxicity of heavy metals to embryos of the American oyster Crassostrea virginica. Mar. Biol. 18, 162-166.

Carrasco, J. F., Rodríguez, C., Rodríguez, M., 2003. Cultivo intensivo de paralarvas de pulpo (Octopus vulgaris, Cuvier 1797) utilizando como base de la alimentación zoeas vivas de crustáceos. pp.: 255-256. Libro de Resúmenes del IX Congreso Nacional de Acuicultura, Cádiz.

Castillo, L. V., Kawaguchi, S., Maita Y., 1990. Evidence for the presence of heavy metal binding proteins in the squid, Onychoteuthis borealijaponica. In: R. Hirano, R., Hanyu, I. (eds) The Second Asian Fisheries Forum (991 p.). Manila: Asian Fish. Soc.

Castillo, L. V., Maita, Y., 1991. Isolation and partial characterisation of cadmium binding proteins from the oceanic squid, Ommastrephes bartrami. Bull. Fac. Fish. Hokkaido Univ. 42(1), 26-34. 
Castro, B., Di Marco, F. P., De Rusha, R. H., Lee, P. G., 1993. The effects of surimi and pelleted diets on the laboratory survival, growth, and feeding rate of the cuttlefish Sepia officinalis L. J. Exp. Mar. Biol. Ecol. 170, 241-252.

Craig, S., Overnell, J., 2003. Metals in squid, Loligo forbesi, adults, eggs and hatchlings. No evidence for a role for $\mathrm{Cu}$ - or Zn-metallothionein. Comp. Biochem. Physiol. C. 134, 311-317.

D'Aniello, A., Strazzullo, L., D'Onofrio, G., Pischetola, M., 1986. Electrolytes and nitrogen compounds of body fluids and tissues of Octopus vulgaris Lam. J. Comp. Physiol. 156, 503-509.

Decleir, W., Lemaire, J., Richard, A., 1970. Determination of copper in embryos and very young specimens of Sepia officinalis. Mar. Biol. 5, 256-258.

Domingues, P. M., Sykes, A., Andrade, J. P., 2001. The use of Artemia sp. or mysids as food source for hatchlings of the cuttlefish (Sepia officinalis L.); effects on growth and survival throughout the life cycle. Aquaculture International 9, 319-331.

Domingues, P., Poirier, R., Dickel, L., Almansa, E., Sykes, A., Andrade, J. P., 2003. Effects of culture density and live prey on growth and survival of juvenile cuttlefish, Sepia officinalis. Aquaculture International 11, 225-242.

Finger, J. M., Smith, J. D., 1987. Molecular association of $\mathrm{Cu}, \mathrm{Zn}, \mathrm{Cd},{ }^{210} \mathrm{Po}$ in the digestive gland of the squid Nototodarus gouldi. Mar. Biol. 95, 87-91.

García García, J., Rodríguez, L. M., García García, B., 2004. Cost analysis of octopus ongrowing installation in Galicia. Span. J. Agric. Res. 2, 531-537.

García García, B., Cerezo Valverde, J., 2006. Optimal proportions of crabs and fish in diet for common octopus (Octopus vulgaris) ongrowing. Aquaculture 253, 502-511.

Gerpe, M. S., de Moreno, J. E. A., Moreno, V. J., Patat, M. L., 2000. Cadmium, zinc and copper accumulation in the squid Illex argentinus from the Southwest Atlantic Ocean. Mar. Biol. 136, 1039-1044.

Ghiretti-Magaldi, A., Giuditta, A., Ghiretti, F., 1958. Pathways of terminal respiration in marine invertebrates. I. The respiratory system in cephalopods. J. Cell. Comp. Physiol. 52, 389-429.

Ghiretti, F., 1966. Molluscan hemocyanins. In: Wilbur, K.M., Yonge, C.M. (Eds.), Physiology of Mollusca, vol. II. Academic Press, London, New York, pp. 233-248.

Guary, J-C., Higgo, J.J.W., Cherry, R.D., Heyraud, M., 1981. High concentrations of transuranic and natural radioactive elements in the branchial hearts of the cephalopod Octopus vulgaris. Mar. Ecol. Prog. Ser. 4, 123-126.

Hanlon, R. T., Bidwell, J. P., Tait, R., 1989. Strontium is required for statolith development and thus normal swimming behaviour of hatchling cephalopods. J. Exp. Biol. 141, 187-195.

Hernández-García, V., Martín, A.Y., Castro, J.J., 2000. Evidence of external digestion of crustaceans in Octopus vulgaris paralarvae. J. Mar. Biol. Ass. U.K. 80, 559-560.

Hossain, M. A., Furuichi, M., 2000. Essentiality of dietary calcium supplement in fingerling scorpion fish (Sebastiscus marmoratus). Aquaculture 189, 155-163.

Hunt, S., Nixon, M., 1981. A comparative study of protein composition in the chitin-protein complexes of the beak, pen, sucker disc, radula and oesophageal cuticle of cephalopods. Comp. Biochem. Physiol. 68B, 535-546.

Hurley, G.V., Odense, P.H., O'Dor, R.K., Dawe, E.G., 1985. Strontium labelling for verifying daily growth increments in the statolith of the short-finned squid (Illex illecebrosus). Can. J. Fish Aquat. Sci. 42, 380383. 
Ichihashi, H., Kohno, H., Kannan, K., Tsumura, A., Yamasaki, S., 2001a. Multielemental analysis of purpleback flying squid using high resolution inductively coupled plasma-mass spectrometry (HR ICPMS). Environ. Sci. Technol. 35, 3103-3108.

Ichihashi, H., Nakamura, Y., Kannan, K., Tsumura, A., Yamasaki, S., 2001b. Multi-elemental concentrations in tissues of Japanese common squid (Todarodes pacificus). Arch. Environ. Contam. Toxicol. 41, 483-490.

Iglesias, J., Otero, J. J., Moxica, C., Fuentes, L., Sánchez, F. J., 2004. The completed life cycle of the octopus (Octopus vulgaris, Cuvier) under culture conditions: paralarval rearing using Artemia and zoeae, and first data on juvenile growth up to eight months of age. Aquacult. Internat. 12, 481-487.

Ikeda, Y., Arai, N., Sakamoto, W., Yoshida, K., 1999. Trace elements in cephalopod calcified tissue: cuttlebone as a possible tracer for life historical events of cuttlefish. Int. J. PIXE 9, 335-343.

Itami, K., Izawa, Y., Maeda, S., Nakai, K., 1963. Notes on the laboratory culture of the octopus larvae. Nippon Suisan Gakkaishi 29, 514-520 (In Japanese with English abstract).

King, I., Childs, M. T., Dorsett, C., Ostrander, J. G., Monsen, E. R., 1990. Shellfish: proximate composition, minerals, fatty acids, and sterols. J. Amer. Diet. Ass. 90, 677-685.

Koueta, N., Boucaud-Camou, E., Noël, B., 2002. Effect of enriched natural diet on survival and growth of juvenile cuttlefish Sepia officinalis L. Aquaculture 203, 293-310.

Koueta, N., Boucaud-Camou, E., 2003. Combined effects of photoperiod and feeding frequency on survival and growth of juvenile cuttlefish Sepia officinalis L. in experimental rearing. J. Exp. Mar. Biol. Ecol. 296, 215-226.

Lall, S. P., 2002. The minerals. In: Halver, J. E. and Hardy, R. W., Editors, 2002. Fish Nutrition (3rd ed.), Academic Press, San Diego, CA, pp. 259-308.

Lee, P. G., 1994. Nutrition of cephalopods: fuelling the system. Mar. Fresh. Behav. Physiol. 25, 35-51.

Martin, J. H., Flegal, A. R., 1975. High copper concentrations in squid livers in association with elevated levels of silver, cadmium, and zinc. Mar. Biol. 30, 51-55.

Martin, M., Osborn, K. E., Billig, P., Glickstein, N., 1981. Toxicities of ten metals to Crassostrea gigas and

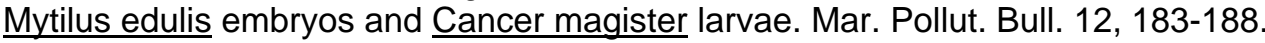

Mason, A. Z., Jenkins, K. D., 1995. Metal detoxification in aquatic organisms. In: Metal speciation and bioavailability in aquatic systems. Tessier, A., Turner, D.R. (eds) Wiley \& Sons, Chichester, Vol. 3, 469608.

Miramand, P., Guary, J. C., 1980. High concentrations of some heavy metals in tissues of the Mediterranean octopus. Bull. Environ. Contam. Toxicol. 24, 783-788.

Miramand, P., Bentley, D., 1992. Concentration and distribution of heavy metals in tissues of two cephalopods, Eledone cirrhosa and Sepia officinalis, from the French coast of the English Channel. Mar. Biol. 114, 407-414.

Miramand, P., Bustamante, P., Bentley, D., Kouéta, N., 2006. Variation of heavy metal concentrations (Ag, Cd, Co, Cu, Fe, Pb, V, Zn) during the life cycle of the common cuttlefish Sepia officinalis. Sci. Tot. Environ. 361, 132-143

Miyazaki, T., Nakahara, M., Ishii, T., Aoki, K., Watabe, T., 2001. Accumulation of cobalt in newly hatched octopus Octopus vulgaris. Fish. Sci. 67, 170-172.

Nabhitabhata, J., Nilaphat, P., Promboon, P., Jaroongpattananon, C., Nilaphat, G., Reunreng, A., 2005. Performance of simple large-scale cephalopod culture system in Thailand. Phuket mar. biol. Cent. Res. Bull. 6, 337-350. 
Naef, A., 1928. Cephalopoda, Embryology. Part I, Vol II (Final part of Monograph No. 35). In: Fauna and Flora of the Bay of Naples, 35, 1- 461. Translated by the Smithsonian Institution Libraries, Washington, D.C. 2000.

Napoleao, P., Pinheiro, T., Reis, C. S., 2005a. Elemental characterization of tissues of Octopus vulgaris along the Portuguese coast. Sci. Tot. Environ. 345, 41-49.

Napoleao, P., Reis, C.S., Alves, L.C., Pinheiro, T., 2005b. Morphologic characterisation and elemental distribution of Octopus vulgaris Cuvier, 1797 vestigial shell. Nuc. Inst. Meth. B. 231, 345-349.

Nardi, G., Muzii, E.O., Puca, M., 1971. Ferritin in the hepatopancreas of Octopus vulgaris Lam. Comp. Biochem. Physiol. 40B,199-205.

Nardi, G., Steinberg, H., 1974. Isolation and distribution of adenochrome(s) in Octopus vulgaris. Comp. Biochem. Physiol. 48 B, 453-461.

Navarro, J.C., Villanueva, R., 2000. Lipid and fatty acid composition of early stages of cephalopods: an approach to their lipid requirements. Aquaculture 183, 161-177.

Navarro, J.C., Villanueva, R., 2003. The fatty acid composition of Octopus vulgaris paralarvae reared with live and inert food: deviation from their natural fatty acid profile. Aquaculture 219, 613-631.

Nixon, M., 1987. Cephalopod diets. In: Boyle, P.R. (Ed.), Cephalopod Life Cycles, Vol. 2. Academic Press, London. pp. 201-219.

O'Dor, R.K., Mangold, K., Boucher-Rodoni, R., Wells, M.J., Wells, J., 1984. Nutrient absorption, storage and remobilizaion in Octopus vulgaris. Mar. Behav. Physiol. 11, 239-258.

Okumura, S; Kurihara, A, Iwamoto, A, Takeuchi, T., 2005. Improved survival and growth in Octopus vulgaris paralarvae by feeding large type Artemia and Pacific sandeel, Ammodytes personatus Aquaculture 244, 147-157.

Passarella, K.C., Hopkins, T.L., 1991. Species composition and food habits of the micronektonic cephalopod assemblage in the Eastern Gulf of Mexico. Bull. Mar. Sci. 49, 638-659.

Paulij, W. P., Zurburg, J. M., Denucé, J. M., van Hannen, E. J., 1990. The effect of copper on the embryonic development and hatching of Sepia officinalis L. Arch. Environ. Contam. Toxicol. 19, 797-801.

Rainbow, P.S., 1988. The significance of trace metal concentrations in decapods. Symp. Zool. Soc. Lond. 59, 291-313.

Renzoni, A., Bacci, E., Falciai, L., 1973. Mercury concentration in the water, sediments and fauna of an area of the Tyrrhenian coast. Rev. Int. Océanogr. Méd. 31-32, 17-45.

Rocca, E., 1969. Copper distribution in Octopus vulgaris Lam. hepatopancreas. Comp. Biochem. Physiol. 28, 67-82.

Rosenlund, G., Stoss, J., Talbot, C., 1997. Co-feeding marine fish larvae with inert and live diets. Aquaculture 155, 183-191.

Sarzanini, C., Mentasti, E., Abollino, O., Fasano, M., Aime, S., 1992. Metal content in Sepia officinalis melanin. Mar. Chem. 39, 243-250.

Seixas, S., Bustamante, P., Pierce, G.J., 2005. Interannual patterns of variation in concentrations of trace elements in arms of Octopus vulgaris. Chemosphere 59, 1113-1124.

Skonberg, D.I, Perkins, B.L., 2002. Nutrient composition of green crab (Carcinus maenas) leg meat and claw meat. Food Chem. 77, 401-404.

Simkiss, K., 1979. Metal ions in cells. Endeavour, New Series 3, 2-6. 
Smith, J.D., Plues, L., Heyraud, M., Cherry, R.D., 1984. Concentrations of the elements Ag, Al, Ca, Cd, $\mathrm{Cu}, \mathrm{Fe}, \mathrm{Mg}, \mathrm{Pb}$ and $\mathrm{Zn}$, and the radionuclides ${ }^{210} \mathrm{~Pb}$ and ${ }^{210} \mathrm{Po}$ in the digestive gland of the squid Nototodarus gouldi. Mar. Environ. Res. 13, 55-68.

Stowasser, G., Bustamante, P., MacLeod, C. D., Wang, J., Pierce, G. J., 2005. Spawning areas and toxic element levels in squid (Loligo forbesi) in UK waters, with notes on toxic element levels in other squid species. Report for the UK Department of Trade and Industry's offshore energy Strategic Environmental Assessment programme. $41 \mathrm{p}$.

Suzuki, Y., Nakahara, M., Nakamura, R., 1978. Accumulation of cesium-137 by useful Mollusca. Bull. Jpn. Soc. scient. Fish. 44, 325-329.

Sykes, A. V., Domingues, P. M., Correia, M., Andrade, J. P. 2006. Cuttlefish culture - state of the art and future trends. Vie et Milieu 56, 129-137.

Tan, B., Mai, K., Liufu, Z., 2001. Response of juvenile abalone, Haliotis discus hannai, to dietary calcium, phosphorus and calcium/phosphorus ratio. Aquaculture 198, 141-158.

Tanaka, T., Hayashi, Y., Ishizawa, M.,1983. Subcellular distribution and binding of heavy metals in the untreated liver of the squid; comparison with data from the livers of cadmium and silver exposed rats. Experientia 39, 746-748.

Taylor, H. H., Anstiss, J.M, 1999. Copper and haemocyanin dynamics in aquatic invertebrates. Mar. Fresh. Res. 50: 907-931.

Vecchione, M., 1991. A method for examining the structure and contents of the digestive tract in paralarval squids. Bull. Mar. Sci. 49, 300-308.

Villanueva, R., 1992. Continuous spawning in the cirrate octopods Opisthoteuthis agassizii and $\underline{\mathrm{O}}$. vossi: features of sexual maturation defining a reproductive strategy in cephalopods. Mar. Biol. 114: 265-275.

Villanueva, R., 1994. Decapod crab zoeae as food for rearing cephalopod paralarvae. Aquaculture 128, 143-152.

Villanueva, R., 1995. Experimental rearing and growth of planktonic Octopus vulgaris from hatching to settlement. Can. J. Fish. Aquat. Sci. 52, 2639-2650.

Villanueva, R., Nozais, C., Boletzky, S.v., 1995. The planktonic life of octopuses. Nature 377, 107.

Villanueva, R., Nozais, C., Boletzky, S.v., 1996. Swimming behaviour and food searching in planktonic Octopus vulgaris Cuvier from hatching to settlement. J. Exp. Mar. Biol. Ecol. 208, 169-184

Villanueva, R., Koueta, N., Riba, J., Boucaud-Camou, E., 2002. Growth and proteolytic activity of Octopus vulgaris paralarvae with different food rations during first-feeding, using Artemia nauplii and compound diets. Aquaculture 205, 269-286.

Villanueva, R., Riba, J., Ruíz-Capillas, C., González, A. V., Baeta, M., 2004. Amino acid composition of early stages of cephalopods and effect of amino acid dietary treatments on Octopus vulgaris paralarvae. Aquaculture 242, 455-478.

Walsh, L. S., Turk, P. E., Forsythe, J. W., Lee, P. G., 2002. Mariculture of the loliginid squid Sepioteuthis lessoniana through seven successive generations. Aquaculture 212, 245-262.

Warnau, M., Laccarino, M., De Biase, A., Temara, A., Jangoux, M., Dubois, Ph., Pagano, G., 1996. Spermiotoxicity and embryotoxicity of heavy metals in the echinoid Paracentrotus lividus. Environ. Toxicol. Chem. 15, 1931-1936.

Watanabe, T., Kiron, V., Satoh, S., 1997. Trace minerals in fish nutrition. Aquaculture 15, 185-207.

Wells, M. J., Wells, J., 1989. Water uptake in a cephalopod and the function of the so-called "pancreas". J. Exp. Biol. 145, 215-226. 
White, S. L., Rainbow, P.S., 1985. On the metabolic requirements for cooper and zinc in molluscs and crustaceans. Mar. Environ. Res. 16, 215-229.

Williams, R. J. P., 1981 Natural selection of the chemical elements. Proc. Royal Soc. B 213, 361-397.

Yamada, M., Aono, T., Hirano, S., 1999. ${ }^{239+240} \mathrm{Pu}$ and ${ }^{137} \mathrm{Cs}$ concentrations in fish, cephalopods, crustaceans, shellfish, and algae collected around the Japanese coast in the early 1990s. Sci. Tot. Environ. 239, 131-142.

Zauke, G.P., Petri, G., 1993. Metal concentrations in Antarctic crustacean: the problem of background levels. In: Dallinger R, Rainbow PS (eds) Ecotoxicology of metals in Invertebrates. Lewis publishers, London, pp 73-101.

Zumholz, K., Hansteen, T.H., Klügel, A., Piatkowski, U., 2006. Food effects on statolith composition of the common cuttlefish (Sepia officinalis). Mar. Biol. (in press) 
Table 1. Means \pm SD of the wet and dry weights (in $\mathrm{mg}_{\text {ind }}{ }^{-1}$ ), and the essential and non-essential elemental content (in $\mu \mathrm{g} \mathrm{g^{-1 }}$ of dry weight) of Sepia officinalis, Loligo vulgaris and Octopus vulgaris hatchlings. Elemental analyses were made from at least three replicates. Means \pm SD with same superscript letters for the same element, denotes no statistical differences within the species $(P>0.05)$.

\begin{tabular}{|c|c|c|c|}
\hline & Sepia officinalis & Loligo vulgaris & Octopus vulgaris \\
\hline Wet weight & $82.1 \pm 5.3$ & $3.5 \pm 0.1$ & $2.1 \pm 0.1$ \\
\hline Dry weight & $20.8 \pm 1.0$ & $0.8 \pm 0.0$ & $0.3 \pm 0.0$ \\
\hline \multicolumn{4}{|c|}{ Major essential elements } \\
\hline $\mathrm{Ca}$ & $12158 \pm 1055^{\mathrm{a}}$ & $1562 \pm 50^{b}$ & $2496 \pm 52^{b}$ \\
\hline K & $15363 \pm 1518^{b}$ & $18426 \pm 324^{\mathrm{a}}$ & $17801 \pm 429^{a}$ \\
\hline $\mathrm{Mg}$ & $2342 \pm 408^{b}$ & $1720 \pm 24^{c}$ & $3270 \pm 126^{a}$ \\
\hline $\mathrm{Na}$ & $13792 \pm 1387^{c}$ & $8392 \pm 251^{b}$ & $17815 \pm 585^{a}$ \\
\hline $\mathrm{P}$ & $11311 \pm 519^{b}$ & $13103 \pm 90^{\mathrm{a}}$ & $13382 \pm 279^{a}$ \\
\hline S & $22980 \pm 1650^{b}$ & $26077 \pm 342^{\mathrm{a}}$ & $28647 \pm 761^{a}$ \\
\hline \multicolumn{4}{|c|}{ Minor essential elements } \\
\hline As & $144 \pm 4^{a}$ & $53.0 \pm 0.4^{c}$ & $78.6 \pm 1.8^{b}$ \\
\hline $\mathrm{Cr}$ & $<2$ & $<2$ & $<2$ \\
\hline Co & $<0.07$ & $<0.07$ & $<0.07$ \\
\hline $\mathrm{Cu}$ & $58.6 \pm 10.7^{b}$ & $69.8 \pm 1.9^{b}$ & $217 \pm 3.0^{\mathrm{a}}$ \\
\hline $\mathrm{Fe}$ & $19 \pm 2^{\mathrm{a}}$ & $23 \pm 2^{a}$ & $21 \pm 1^{a}$ \\
\hline Mn & $1.9 \pm 0.1^{b}$ & $1.6 \pm 0.0^{c}$ & $3.7 \pm 0.1^{\mathrm{a}}$ \\
\hline $\mathrm{Ni}$ & $<0.5$ & $<0.5$ & $1.3 \pm 0.1$ \\
\hline $\mathrm{Rb}$ & $5.8 \pm 0.5^{b}$ & $8.1 \pm 0.1^{\mathrm{a}}$ & $7.9 \pm 0.2^{\mathrm{a}}$ \\
\hline $\mathrm{Sr}$ & $107 \pm 10^{\mathrm{a}}$ & $24.8 \pm 0.8^{c}$ & $43.8 \pm 1.3^{b}$ \\
\hline $\mathrm{Zn}$ & $101 \pm 10^{b}$ & $105 \pm 2^{b}$ & $182 \pm 5^{a}$ \\
\hline \multicolumn{4}{|c|}{ Non-essential elements } \\
\hline $\mathrm{Ag}$ & $0.5 \pm 0.2^{b}$ & $0.8 \pm 0.0^{b}$ & $2.8 \pm 0.1^{\mathrm{a}}$ \\
\hline $\mathrm{Al}$ & $10.2 \pm 4.0^{\mathrm{a}}$ & $10.9 \pm 2.6^{\mathrm{a}}$ & $<10$ \\
\hline $\mathrm{Ba}$ & $0.2 \pm 0.0$ & $<0.1$ & $<0.1$ \\
\hline $\mathrm{Cd}$ & $<0.07$ & $<0.07$ & $<0.07$ \\
\hline $\mathrm{Hg}$ & $0.3 \pm 0.0^{\mathrm{a}}$ & $0.1 \pm 0.0^{b}$ & $0.2 \pm 0.0^{\mathrm{a}}$ \\
\hline $\mathrm{Pb}$ & $0.3 \pm 0.1^{b}$ & $0.3 \pm 0.1^{b}$ & $0.4 \pm 0.0^{\mathrm{a}}$ \\
\hline
\end{tabular}

0.0 are values below 0.05 
Table 2. Means \pm SD and range of the wet and dry weigths (in $\mathrm{mg} \mathrm{ind}^{-1}$ ), and the essential and non-essential elemental content (in $\mu g \mathrm{~g}^{-1}$ of dry weight) in six individuals of Sepia officinalis, and five individuals of Loligo vulgaris and Octopus vulgaris wild juveniles. Elemental analysis were made from at least three replicates for each individual, with the exception for an 0 . vulgaris specimen $3671 \mathrm{mg}$ dry weight, with only two replicates. Correlation $\left(R^{2}\right)$ between dry weight and concentration of the element is indicated and probability values $(P)$ with significant correlations are indicated in bold face. Elemental content in these wild juveniles in comparison with hatchling content is also indicated. N.S., not significant differences, $\mathrm{P}>0.05$.

\begin{tabular}{|c|c|c|c|c|c|}
\hline Sepia officinalis & Mean \pm SD & range & $\mathrm{R}^{2}$ & $P$ & Comparison with hatchling content \\
\hline Wet weight & $63643 \pm 32993$ & $25870-103757$ & & & \\
\hline Dry weight & $15880 \pm 8490$ & $6265-26285$ & & & \\
\hline \multicolumn{6}{|c|}{ Major essential elements } \\
\hline $\mathrm{Ca}$ & $41529 \pm 2964$ & $37972-46956$ & 0.10 & 0.19 & High in juveniles \\
\hline K & $13390 \pm 399$ & $12816-14242$ & -0.00 & 0.79 & High in hatchlings \\
\hline $\mathrm{Mg}$ & $3509 \pm 485$ & $2880-4571$ & 0.00 & 0.94 & High in juveniles \\
\hline $\mathrm{Na}$ & $16827 \pm 640$ & $15736-17780$ & -0.22 & 0.05 & High in juveniles \\
\hline $\mathrm{P}$ & $9728 \pm 372$ & $9136-10412$ & -0.03 & 0.50 & High in hatchlings \\
\hline S & $23260 \pm 780$ & 21611-24663 & 0.13 & 0.14 & N.S. \\
\hline \multicolumn{6}{|c|}{ Minor essential elements } \\
\hline As & $70.6 \pm 9.5$ & $59.2-83.6$ & 0.00 & 0.94 & High in hatchlings \\
\hline $\mathrm{Cr}$ & $<10$ & & & & \\
\hline Co & $0.9 \pm 0.1$ & $0.6-1.0$ & 0.00 & 0.81 & High in juveniles \\
\hline $\mathrm{Cu}$ & $190 \pm 37$ & $131-242$ & 0.30 & 0.02 & High in juveniles \\
\hline $\mathrm{Fe}$ & $336 \pm 272$ & $90-869$ & -0.71 & 0.00 & N.S. \\
\hline $\mathrm{Mn}$ & $5.7 \pm 3.8$ & $2.4-13.5$ & -0.66 & 0.00 & N.S. \\
\hline $\mathrm{Ni}$ & $<5$ & & & & \\
\hline $\mathrm{Rb}$ & $5.5 \pm 0.4$ & $5.0-6.1$ & -0.53 & 0.00 & N.S. \\
\hline $\mathrm{Sr}$ & $354 \pm 31$ & $315-422$ & 0.26 & 0.03 & High in juveniles \\
\hline $\mathrm{Zn}$ & $146 \pm 19$ & $118-183$ & 0.51 & 0.00 & High in juveniles \\
\hline \multicolumn{6}{|c|}{ Non-essential elements } \\
\hline Al & $183 \pm 160$ & $24.9-485$ & -0.78 & 0.00 & N.S. \\
\hline $\mathrm{Ag}$ & $3.1 \pm 0.8$ & $1.9-4.7$ & -0.12 & 0.16 & High in juveniles \\
\hline $\mathrm{Ba}$ & $2.9 \pm 1.8$ & $1.0-6.9$ & -0.58 & 0.00 & High in juveniles \\
\hline $\mathrm{Cd}$ & $0.9 \pm 0.2$ & $1.0-6.9$ & 0.03 & 0.48 & High in juveniles \\
\hline $\mathrm{Hg}$ & $0.5 \pm 0.2$ & $0.3-0.9$ & -0.12 & 0.16 & High in juveniles \\
\hline $\mathrm{Pb}$ & $1.1 \pm 0.4$ & $0.6-1.9$ & -0.78 & 0.00 & High in juveniles \\
\hline
\end{tabular}

0.0 are values below 0.05 
Table 2 (cont.)

\begin{tabular}{llllll}
\hline Loligo vulgaris & Mean $\pm \mathrm{SD}$ & range & $\mathrm{R}^{2}$ & $\mathrm{P}$ & $\begin{array}{l}\text { Comparison with } \\
\text { hatchling content }\end{array}$ \\
\hline Wet weight & $2306 \pm 372$ & $1993-2779$ & & & \\
Dry weight & $472 \pm 86$ & $394-571$ & & & \\
Major essential elements & & & & & \\
$\mathrm{Ca}$ & $1776 \pm 729$ & $1106-3450$ & -0.03 & 0.54 & N.S. \\
$\mathrm{K}$ & $12464 \pm 612$ & $11538-13546$ & $\mathbf{0 . 6 8}$ & $\mathbf{0 . 0 0}$ & High in hatchlings \\
$\mathrm{Mg}$ & $3040 \pm 263$ & $2706-3511$ & -0.10 & 0.25 & High in juveniles \\
$\mathrm{Na}$ & $19087 \pm 1961$ & $16604-22555$ & -0.26 & 0.05 & High in juveniles \\
$\mathrm{P}$ & $10963 \pm 415$ & $10170-11487$ & 0.26 & 0.05 & High in hatchlings \\
$\mathrm{S}$ & $22859 \pm 1074$ & $20821-24510$ & 0.27 & 0.04 & High in hatchlings \\
$\mathrm{Minor}$ essential elements & & & & & \\
$\mathrm{As}$ & $15.3 \pm 1.7$ & $12.9-17.2$ & -0.06 & 0.37 & High in hatchlings \\
$\mathrm{Cr}$ & $<2$ & & & & \\
$\mathrm{Co}$ & $<0.07$ & & & & \\
$\mathrm{Cu}$ & $49.1 \pm 6.3$ & $38.8-58.4$ & 0.03 & 0.52 & High in hatchlings \\
$\mathrm{Fe}$ & $74 \pm 30$ & $32-132$ & $\mathbf{0 . 3 8}$ & $\mathbf{0 . 0 1}$ & High in juveniles \\
$\mathrm{Ni}$ & $<0.5$ & & & & \\
$\mathrm{Mn}$ & $2.4 \pm 0.5$ & $1.6-3.5$ & 0.21 & 0.09 & High in juveniles \\
$\mathrm{Rb}$ & $4.9 \pm 0.4$ & $4.2-5.5$ & $\mathbf{0 . 8 9}$ & $\mathbf{0 . 0 0}$ & High in hatchlings \\
$\mathrm{Sr}$ & $22.8 \pm 10.9$ & $13.7-47.5$ & -0.04 & 0.48 & N.S. \\
$\mathrm{Zn}$ & $60.4 \pm 3.7$ & $54.0-67.5$ & 0.01 & 0.80 & High in hatchlings \\
$\mathrm{Non}-\mathrm{Na}$ & & & & \\
$\mathrm{Ag}$ & $1.0 \pm 0.2$ & $0.6-1.4$ & $-\mathbf{0 . 3 7}$ & $\mathbf{0 . 0 2}$ & N.S. \\
$\mathrm{Al}$ & $56.9 \pm 27.8$ & $19.4-103$ & $\mathbf{0 . 3 3}$ & $\mathbf{0 . 0 3}$ & High in juveniles \\
$\mathrm{Ba}$ & $1.4 \pm 1.3$ & $0-3-3.9$ & -0.12 & 0.21 & High in juveniles \\
$\mathrm{Cd}$ & $0.3 \pm 0.0$ & $0.2-0.3$ & 0.01 & 0.72 & High in juveniles \\
$\mathrm{Hg}$ & $0.2 \pm 0.0$ & $0.1-0.2$ & -0.09 & 0.35 & N.S. \\
$\mathrm{Pb}$ & $0.6 \pm 0.2$ & $0.4-1.1$ & 0.07 & 0.34 & High in juveniles \\
\hline & & & &
\end{tabular}

0.0 are values below 0.05 
Table 2 (cont.)

\begin{tabular}{|c|c|c|c|c|c|}
\hline Octopus vulgaris & Mean \pm SD & Range & $\mathrm{R}^{2}$ & $P$ & Comparison with hatchling content \\
\hline Wet weight & $7846 \pm 4553$ & 3305-14188 & & & \\
\hline Dry weight & $1836 \pm 1145$ & 814-3671 & & & \\
\hline \multicolumn{6}{|c|}{ Major essential elements } \\
\hline $\mathrm{Ca}$ & $2180 \pm 886$ & 1103-3657 & 0.03 & 0.57 & N.D. \\
\hline K & $14007 \pm 1159$ & $11790-16791$ & 0.13 & 0.18 & high in hatchlings \\
\hline $\mathrm{Mg}$ & $3420 \pm 225$ & 2963-37-28 & 0.06 & 0.36 & N.D. \\
\hline $\mathrm{Na}$ & $22217 \pm 2367$ & $19074-26485$ & 0.03 & 0.57 & high in juveniles \\
\hline$P$ & $8342 \pm 554$ & 7179-9631 & 0.39 & 0.01 & high in hatchlings \\
\hline S & $26389 \pm 1883$ & 23241-30566 & 0.29 & 0.04 & N.D. \\
\hline \multicolumn{6}{|c|}{ Minor essential elements } \\
\hline As & $104 \pm 18$ & $74-134$ & 0.03 & 0.55 & high in juveniles \\
\hline $\mathrm{Cr}$ & $<5$ & & & & \\
\hline Co & $0.9 \pm 0.3$ & $0.5-1.7$ & -0.41 & 0.01 & high in juveniles \\
\hline $\mathrm{Cu}$ & $159 \pm 41$ & $108-229$ & -0.17 & 0.14 & high in hatchlings \\
\hline $\mathrm{Fe}$ & $151 \pm 43$ & $83-238$ & 0.00 & 0.92 & high in juveniles \\
\hline Mn & $3.8 \pm 1.1$ & $2.3-5.5$ & -0.00 & 0.94 & N.D. \\
\hline $\mathrm{Ni}$ & $1.4 \pm 0.4$ & $0.9-2.1$ & -0.25 & 0.07 & N.D. \\
\hline $\mathrm{Rb}$ & $5.5 \pm 0.4$ & $4.8-6.3$ & 0.09 & 0.28 & high in hatchlings \\
\hline $\mathrm{Sr}$ & $26.2 \pm 7.7$ & $15.9-36.9$ & 0.00 & 0.97 & high in hatchlings \\
\hline $\mathrm{Zn}$ & $135 \pm 22$ & $111-194$ & -0.25 & 0.07 & high in hatchlings \\
\hline \multicolumn{6}{|c|}{ Non-essential elements } \\
\hline $\mathrm{Ag}$ & $2.1 \pm 0.5$ & 1.4-3.1 & -0.02 & 0.66 & high in hatchlings \\
\hline Al & $67.7 \pm 31.0$ & $27.2-119$ & -0.16 & 0.22 & high in juveniles \\
\hline $\mathrm{Ba}$ & $0.6 \pm 0.5$ & $0.2-2.2$ & -0.08 & 0.37 & high in juveniles \\
\hline $\mathrm{Cd}$ & $1.7 \pm 0.6$ & $1.2-3.7$ & -0.40 & 0.02 & high in juveniles \\
\hline $\mathrm{Hg}$ & $0.3 \pm 0.1$ & $0.2-0.5$ & -0.07 & 0.36 & N.D. \\
\hline $\mathrm{Pb}$ & $1.7 \pm 1.4$ & $0.6-6.3$ & -0.12 & 0.23 & N.D. \\
\hline
\end{tabular}

0.0 are values below 0.05 
Table 3. Means \pm SD of the essential and non-essential elemental content (in $\mu \mathrm{g} \mathrm{g}^{-1}$ of dry weight) of mature ovary, spawned eggs at stages I-II and X-XII, hatchlings and hatchlings fasted $4 \mathrm{~d}$ of Octopus vulgaris. Dry weights (in $\mu \mathrm{g} \mathrm{ind}^{-1}$ ) in hatchlings correspond to the means $\pm \mathrm{SD}$. Elemental analyses were made from at least three replicates. Means \pm SD with same superscript letters for ovary and eggs, and for hatchlings and fasted for dry weight and for the same element, denotes no statistical differences within the group $(P>0.05)$.

\begin{tabular}{|c|c|c|c|c|c|c|}
\hline Octopus vulgaris & Mature ovary & Eggs stage I-II & Eggs stage $\mathrm{X}-\mathrm{XII}$ & & Hatchlings $0 \mathrm{~d}$ & Hatchlings fasted $4 \mathrm{~d}$ \\
\hline & & & & Dry weight & $337.9 \pm 10.1^{\mathrm{a}}$ & $244 \pm 5.9^{b}$ \\
\hline \multicolumn{7}{|c|}{ Major esential elements } \\
\hline $\mathrm{Ca}$ & $247 \pm 22^{b}$ & $278 \pm 19^{b}$ & $849 \pm 2^{a}$ & & $2496 \pm 52^{b}$ & $3146 \pm 70^{a}$ \\
\hline K & $3545 \pm 108^{b}$ & $1252 \pm 114^{\mathrm{c}}$ & $8339 \pm 24^{a}$ & & $17801 \pm 429^{a}$ & $15063 \pm 213^{b}$ \\
\hline $\mathrm{Mg}$ & $829 \pm 62^{b}$ & $939 \pm 102^{b}$ & $2030 \pm 17^{\mathrm{a}}$ & & $3270 \pm 126^{a}$ & $3327 \pm 62^{a}$ \\
\hline $\mathrm{Na}$ & $5645 \pm 301^{b}$ & $4857 \pm 663^{b}$ & $10283 \pm 146^{\mathrm{a}}$ & & $17815 \pm 585^{\mathrm{a}}$ & $18620 \pm 350^{\mathrm{a}}$ \\
\hline$P$ & $8581 \pm 132^{a}$ & $7106 \pm 744^{b}$ & $8499 \pm 122^{a}$ & & $13382 \pm 279^{a}$ & $11604 \pm 131^{b}$ \\
\hline S & $19565 \pm 276^{b}$ & $19350 \pm 2054^{b}$ & $23369 \pm 77^{\mathrm{a}}$ & & $28647 \pm 761^{\mathrm{a}}$ & $29597 \pm 444^{\mathrm{a}}$ \\
\hline \multicolumn{7}{|c|}{ Minor essential elements } \\
\hline As & $67.6 \pm 0.4^{\mathrm{a}}$ & $52.3 \pm 5.8^{b}$ & $33.4 \pm 0.9^{c}$ & & $78.6 \pm 1.8^{b}$ & $88.2 \pm 1.1^{\mathrm{a}}$ \\
\hline $\mathrm{Cr}$ & $<2$ & $<2$ & $<2$ & & $<2$ & $<2$ \\
\hline Co & $<0.07$ & $<0.07$ & $<0.07$ & & $<0.07$ & $0.5 \pm 0.0$ \\
\hline $\mathrm{Cu}$ & $38.2 \pm 0.5^{b}$ & $44.2 \pm 5.1^{b}$ & $86.3 \pm 2.0^{\mathrm{a}}$ & & $217 \pm 3.0^{\mathrm{a}}$ & $205 \pm 3.9^{b}$ \\
\hline $\mathrm{Fe}$ & $26 \pm 2^{a}$ & $10 \pm 1^{c}$ & $17 \pm 2^{b}$ & & $21 \pm 1^{b}$ & $31 \pm 1^{a}$ \\
\hline $\mathrm{Mn}$ & $3.0 \pm 0.1^{a}$ & $2.0 \pm 0.2^{b}$ & $3.3 \pm 0.1^{a}$ & & $3.7 \pm 0.1^{\mathrm{a}}$ & $2.7 \pm 0.0^{b}$ \\
\hline $\mathrm{Ni}$ & $<0.5$ & $<0.5$ & $1.1 \pm 0.1$ & & $1.3 \pm 0.1^{\mathrm{a}}$ & $1.3 \pm 0.0^{\mathrm{a}}$ \\
\hline $\mathrm{Rb}$ & $2.0 \pm 0.0^{b}$ & $1.2 \pm 0.1^{c}$ & $3.8 \pm 0.1^{\mathrm{a}}$ & & $7.9 \pm 0.2^{\mathrm{a}}$ & $6.3 \pm 0.1^{b}$ \\
\hline $\mathrm{Sr}$ & $4.2 \pm 0.4^{b}$ & $4.7 \pm 0.5^{b}$ & $13.3 \pm 0.5^{\mathrm{a}}$ & & $43.8 \pm 1.3^{b}$ & $54.8 \pm 1.2^{\mathrm{a}}$ \\
\hline $\mathrm{Zn}$ & $95.2 \pm 1.7^{\mathrm{a}}$ & $72.7 \pm 7.9^{b}$ & $102 \pm 2.0^{\mathrm{a}}$ & & $182 \pm 5.1^{b}$ & $371 \pm 8.4^{a}$ \\
\hline \multicolumn{7}{|c|}{ Non-essential elements } \\
\hline $\mathrm{Ag}$ & $2.3 \pm 0.1^{b}$ & $2.2 \pm 0.3^{b}$ & $12.3 \pm 0.5^{\mathrm{a}}$ & & $2.8 \pm 0.1^{b}$ & $11.3 \pm 3.1^{\mathrm{a}}$ \\
\hline Al & $<10$ & $<10$ & $<10$ & & $<10$ & $<10$ \\
\hline $\mathrm{Ba}$ & $<0.2$ & $<0.2$ & $0.2 \pm 0.0$ & & $<0.1$ & $0.6 \pm 0.0$ \\
\hline $\mathrm{Cd}$ & $<0.07$ & $0.1 \pm 0.0$ & $<0.07$ & & $<0.07$ & $0.3 \pm 0.0$ \\
\hline $\mathrm{Hg}$ & $0.3 \pm 0.0^{a}$ & $<0.14$ & $0.1 \pm 0.0^{b}$ & & $0.2 \pm 0.0^{\mathrm{b}}$ & $0.3 \pm 0.0^{a}$ \\
\hline $\mathrm{Pb}$ & $0.4 \pm 0.0^{b}$ & $0.2 \pm 0.0^{c}$ & $0.6 \pm 0.0^{a}$ & & $0.4 \pm 0.0^{b}$ & $2.1 \pm 0.0^{a}$ \\
\hline
\end{tabular}

0.0 are values below 0.05 


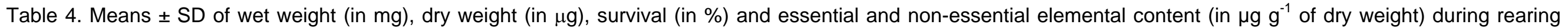
experiments of Octopus vulgaris at the age of $20 \mathrm{~d}$ in four feeding treatments: Control, MET, AA, and METAA (see Material and Methods for details). Elemental analyses were made from at least three replicates. Means $\pm S D$ with same superscript letters for the same row, denotes no statistical differences within the treatments (P>0.05).

\begin{tabular}{lllll}
\hline Octopus vulgaris & Control & MET & AA & METAA \\
\hline Wet weight & $3.4 \pm 0.1^{\mathrm{a}}$ & $3.5 \pm 0.1^{\mathrm{a}}$ & $3.2 \pm 0.2^{\mathrm{b}}$ & $2.8 \pm 0.2^{\mathrm{c}}$ \\
Dry weight & $682.8 \pm 15.4^{\mathrm{a}}$ & $681.6 \pm 28.4^{\mathrm{a}}$ & $653.6 \pm 20.7^{\mathrm{a}}$ & $566.2 \pm 24.5^{\mathrm{b}}$ \\
Survival & $12.6 \pm 3.2^{\mathrm{b}}$ & $17.2 \pm 11.2^{\mathrm{b}}$ & $41.2 \pm 9.9^{\mathrm{a}}$ & $54.1 \pm 4.6^{\mathrm{a}}$
\end{tabular}

\section{Major essential elements}

\begin{tabular}{|c|c|c|c|c|}
\hline $\mathrm{Ca}$ & $1784 \pm 42^{\mathrm{a}}$ & $1840 \pm 356^{\mathrm{a}}$ & $1972 \pm 25^{\mathrm{a}}$ & $2052 \pm 108^{a}$ \\
\hline K & $14533 \pm 220^{a}$ & $14681 \pm 527^{a}$ & $14659 \pm 141^{a}$ & $14050 \pm 217^{a}$ \\
\hline$M g$ & $2762 \pm 6^{c}$ & $2725 \pm 65^{c}$ & $3078 \pm 52^{a}$ & $2900 \pm 41^{b}$ \\
\hline $\mathrm{Na}$ & $15035 \pm 410^{b c}$ & $14501 \pm 839^{c}$ & $17255 \pm 599^{a}$ & $16411 \pm 338^{\mathrm{ab}}$ \\
\hline$P$ & $11321 \pm 112^{a b}$ & $11579 \pm 262^{a}$ & $11439 \pm 189^{a b}$ & $10805 \pm 383^{b}$ \\
\hline $\mathrm{S}$ & $19996 \pm 150^{c}$ & $21418 \pm 651^{b}$ & $23135 \pm 123^{a}$ & $22691 \pm 112^{a}$ \\
\hline \multicolumn{5}{|c|}{ Minor essential elements } \\
\hline As & $44.6 \pm 1.4^{c}$ & $47.8 \pm 0.9^{\mathrm{ab}}$ & $46.8 \pm 0.2^{\mathrm{bc}}$ & $50.4 \pm 1.0^{\mathrm{a}}$ \\
\hline $\mathrm{Cr}$ & $<2$ & $<2$ & $<2$ & $<2$ \\
\hline Co & $0.4 \pm 0.0^{\mathrm{a}}$ & $0.4 \pm 0.0^{\mathrm{a}}$ & $0.4 \pm 0.0^{\mathrm{a}}$ & $0.4 \pm 0.0^{\mathrm{a}}$ \\
\hline $\mathrm{Cu}$ & $91.7 \pm 3.0^{b}$ & $96.5 \pm 4.5^{\mathrm{ab}}$ & $97.4 \pm 0.7^{\mathrm{ab}}$ & $104 \pm 5.3^{\mathrm{a}}$ \\
\hline $\mathrm{Fe}$ & $71 \pm 3^{a}$ & $72 \pm 6^{a}$ & $79 \pm 12^{a}$ & $72 \pm 1^{\mathrm{a}}$ \\
\hline $\mathrm{Mn}$ & $3.4 \pm 0.2^{b}$ & $3.6 \pm 0.1^{\mathrm{ab}}$ & $3.8 \pm 0.0^{\mathrm{a}}$ & $3.4 \pm 0.0^{b}$ \\
\hline $\mathrm{Ni}$ & $1.0 \pm 0.0^{\mathrm{a}}$ & $0.7 \pm 0.1^{b}$ & $0.7 \pm 0.1^{b}$ & $0.5 \pm 0.0^{c}$ \\
\hline $\mathrm{Rb}$ & $6.6 \pm 0.3^{\mathrm{a}}$ & $6.8 \pm 0.2^{\mathrm{a}}$ & $6.9 \pm 0.0^{\mathrm{a}}$ & $6.6 \pm 0.1^{\mathrm{a}}$ \\
\hline $\mathrm{Sr}$ & $30.4 \pm 1.7^{\mathrm{a}}$ & $31.3 \pm 5.1^{\mathrm{a}}$ & $34.4 \pm 1.4^{\mathrm{a}}$ & $36.0 \pm 1.5^{\mathrm{a}}$ \\
\hline Zn & $343 \pm 6.2^{\mathrm{a}}$ & $341 \pm 23^{a}$ & $349 \pm 10.6^{a}$ & $355 \pm 16.3^{a}$ \\
\hline \multicolumn{5}{|c|}{ Non-essential elements } \\
\hline $\mathrm{Ag}$ & $16.5 \pm 0.8^{\mathrm{a}}$ & $14.4 \pm 1.5^{\mathrm{a}}$ & $15.2 \pm 1.7^{\mathrm{a}}$ & $14.7 \pm 1.1^{\mathrm{a}}$ \\
\hline $\mathrm{Al}$ & $<10$ & $<10$ & $<10$ & $<10$ \\
\hline $\mathrm{Ba}$ & $0.4 \pm 0.1^{\mathrm{a}}$ & $0.5 \pm 0.1^{\mathrm{a}}$ & $0.4 \pm 0.0^{\mathrm{a}}$ & $0.5 \pm 0.0^{\mathrm{a}}$ \\
\hline $\mathrm{Cd}$ & $0.3 \pm 0.0^{b}$ & $0.3 \pm 0.0^{\mathrm{ab}}$ & $0.4 \pm 0.4^{a}$ & $0.4 \pm 0.4^{\mathrm{a}}$ \\
\hline $\mathrm{Hg}$ & $0.1 \pm 0.0^{b}$ & $0.2 \pm 0.0^{\mathrm{a}}$ & $<0.1$ & $0.1 \pm 0.0^{\mathrm{ab}}$ \\
\hline $\mathrm{Pb}$ & $1.4 \pm 0.0^{b}$ & $1.7 \pm 0.0^{\mathrm{a}}$ & $1.2 \pm 0.0^{c}$ & $1.2 \pm 0.1^{\mathrm{c}}$ \\
\hline
\end{tabular}

0.0 are values below 0.05 
Table 5. Means \pm SD of the essential and non-essential elemental content (in $\mu \mathrm{g} \mathrm{g}^{-1}$ of dry weight) of Artemia nauplii (used as food during the present study for cultures of Octopus vulgaris paralarvae) and hatchling decapod crab zoeae Maja brachydactyla (used as food for $\underline{O}$. vulgaris paralarvae in previous studies). Artemia SS was enriched only with SuperSelco ${ }^{\circledR}$, Artemia MET was enriched with SuperSelco ${ }^{\circledR}$ plus Methionine (see Material and Methods). Elemental analyses were made from at least three replicates. Means \pm SD with same superscript letters for the same element, denotes no statistical differences within the prey $(P>0.05)$.

\begin{tabular}{llll}
\hline & Artemia SS nauplii & Artemia MET nauplii & Maja brachydactyla zoeae \\
\hline Major essential elements & & & \\
$\mathrm{Ca}$ & $1105 \pm 63^{\mathrm{b}}$ & $1020 \pm 62^{\mathrm{b}}$ & $44533 \pm 2521^{\mathrm{a}}$ \\
$\mathrm{K}$ & $14663 \pm 696^{\mathrm{a}}$ & $14597 \pm 34^{\mathrm{a}}$ & $15003 \pm 168^{\mathrm{a}}$ \\
$\mathrm{Mg}$ & $2210 \pm 112^{\mathrm{b}}$ & $1965 \pm 11^{\mathrm{b}}$ & $10637 \pm 342^{\mathrm{a}}$ \\
$\mathrm{Na}$ & $27301 \pm 1276^{\mathrm{b}}$ & $27493 \pm 240^{\mathrm{b}}$ & $51547 \pm 555^{\mathrm{a}}$ \\
$\mathrm{P}$ & $12119 \pm 320^{\mathrm{a}}$ & $12503 \pm 230^{\mathrm{a}}$ & $12070 \pm 357^{\mathrm{a}}$ \\
$\mathrm{S}$ & $7718 \pm 344^{\mathrm{c}}$ & $10359 \pm 155^{\mathrm{b}}$ & $13449 \pm 422^{\mathrm{a}}$ \\
$\mathrm{Minor}$ essential elements & & & \\
$\mathrm{As}$ & $11.0 \pm 0.4^{\mathrm{b}}$ & $11.4 \pm 0.1^{\mathrm{b}}$ & $47.9 \pm 0.6^{\mathrm{a}}$ \\
$\mathrm{Cr}$ & $<4$ & $<4$ & $<2$ \\
$\mathrm{Co}$ & $0.4 \pm 0.0^{\mathrm{a}}$ & $0.4 \pm 0.0^{\mathrm{a}}$ & $<0.25$ \\
$\mathrm{Cu}$ & $9.5 \pm 0.6^{\mathrm{b}}$ & $7.9 \pm 0.0^{\mathrm{b}}$ & $72.5 \pm 1.4^{\mathrm{a}}$ \\
$\mathrm{Fe}$ & $100 \pm 5^{\mathrm{ab}}$ & $128 \pm 44^{\mathrm{a}}$ & $44 \pm 2^{\mathrm{b}}$ \\
$\mathrm{Mn}$ & $3.4 \pm 0.1^{\mathrm{a}}$ & $3.3 \pm 0.1^{\mathrm{a}}$ & $3.3 \pm 0.3^{\mathrm{a}}$ \\
$\mathrm{Ni}$ & $6.0 \pm 0.3^{\mathrm{a}}$ & $3.5 \pm 0.1^{\mathrm{b}}$ & $<1$ \\
$\mathrm{Rb}$ & $10.6 \pm 0.5^{\mathrm{a}}$ & $10.5 \pm 0.1^{\mathrm{a}}$ & $5.4 \pm 0.0^{\mathrm{b}}$ \\
$\mathrm{Sr}$ & $14.7 \pm 1.0^{\mathrm{b}}$ & $13.0 \pm 0.0^{\mathrm{b}}$ & $564 \pm 35^{\mathrm{a}}$ \\
$\mathrm{Zn}$ & $134 \pm 6.9^{\mathrm{a}}$ & $136 \pm 1.3^{\mathrm{a}}$ & $135 \pm 4.1^{\mathrm{a}}$ \\
$\mathrm{Non}-\mathrm{essential} \mathrm{elements}$ & & & \\
$\mathrm{Ag}$ & $<0.14$ & $<0.14$ & $1.4 \pm 0.1$ \\
$\mathrm{Al}$ & $<10$ & $<10$ & $<10$ \\
$\mathrm{Ba}$ & $0.4 \pm 0.1^{\mathrm{b}}$ & $0.3 \pm 0.0^{\mathrm{b}}$ & $2.4 \pm 0.0^{\mathrm{a}}$ \\
$\mathrm{Cd}$ & $0.1 \pm 0.0^{\mathrm{a}}$ & $0.1 \pm 0.0^{\mathrm{a}}$ & $0.1 \pm 0.0^{\mathrm{a}}$ \\
$\mathrm{Hg}$ & $<0.14$ & $<0.14$ & $0.6 \pm 0.1^{\mathrm{a}}$ \\
$\mathrm{Pb}$ & $0.5 \pm 00^{\mathrm{b}}$ & $0.4 \pm 0.0^{\mathrm{b}}$ & \\
\hline
\end{tabular}

0.0 are values below 0.05 

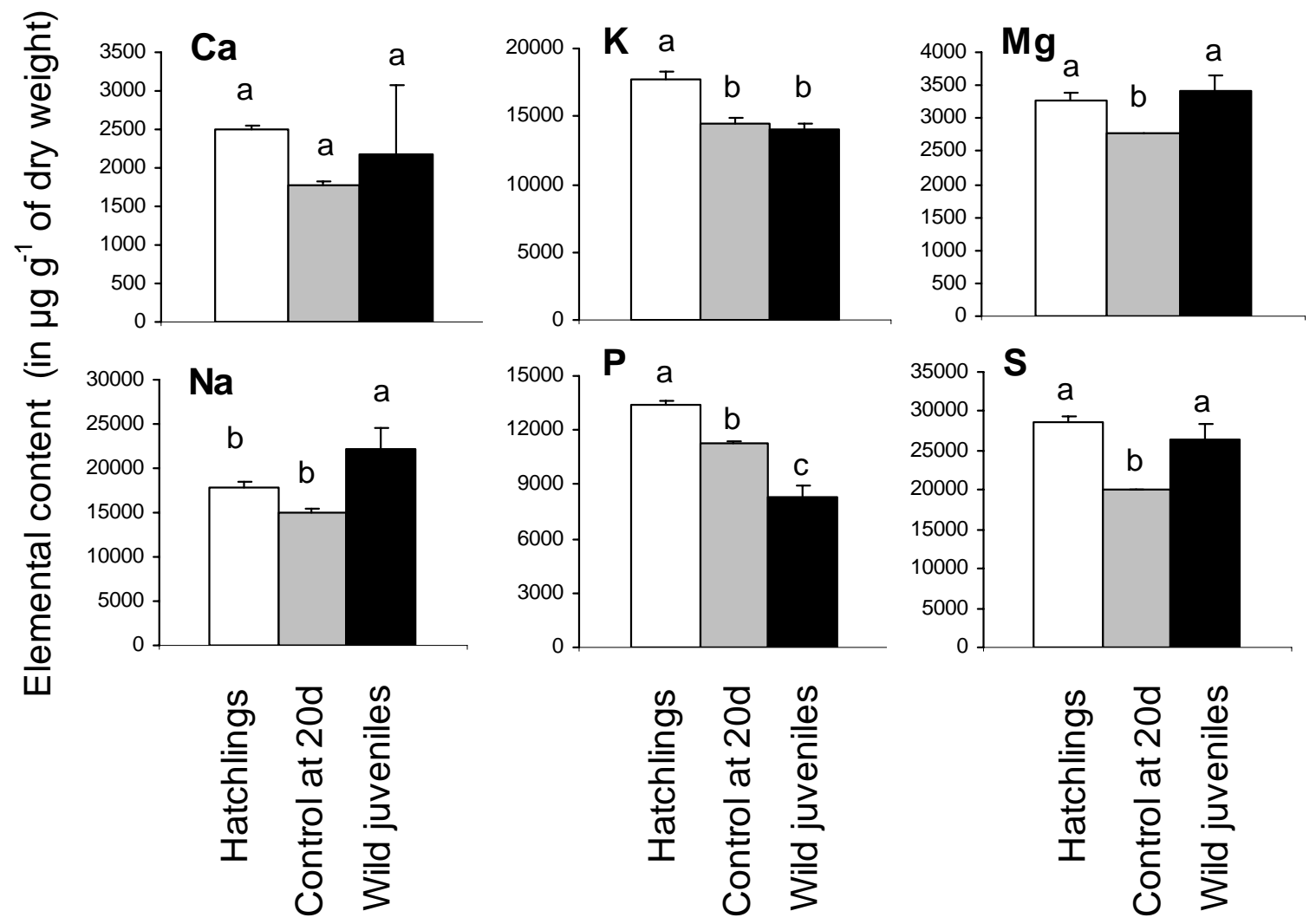

Figure 1. Major essential elements in Octopus vulgaris. Comparison of the mean and standard deviation in content ( $\mu \mathrm{g} \mathrm{g}^{-1}$ dry weight, DW) of $\mathrm{Ca}, \mathrm{K}, \mathrm{Mg}, \mathrm{Na}, \mathrm{P}$ and $\mathrm{S}$ of hatchlings (mean DW $0.34 \mathrm{mg}$ ), reared individuals 20 days old from the control group feed with Artemia nauplii enriched with SuperSelco ${ }^{\circledR}$ (mean DW $0.68 \mathrm{mg}$ ), and wild juveniles (mean DW $1836 \mathrm{mg}$ ). Bars with the same letters are not significantly different $(P>0.05)$. 

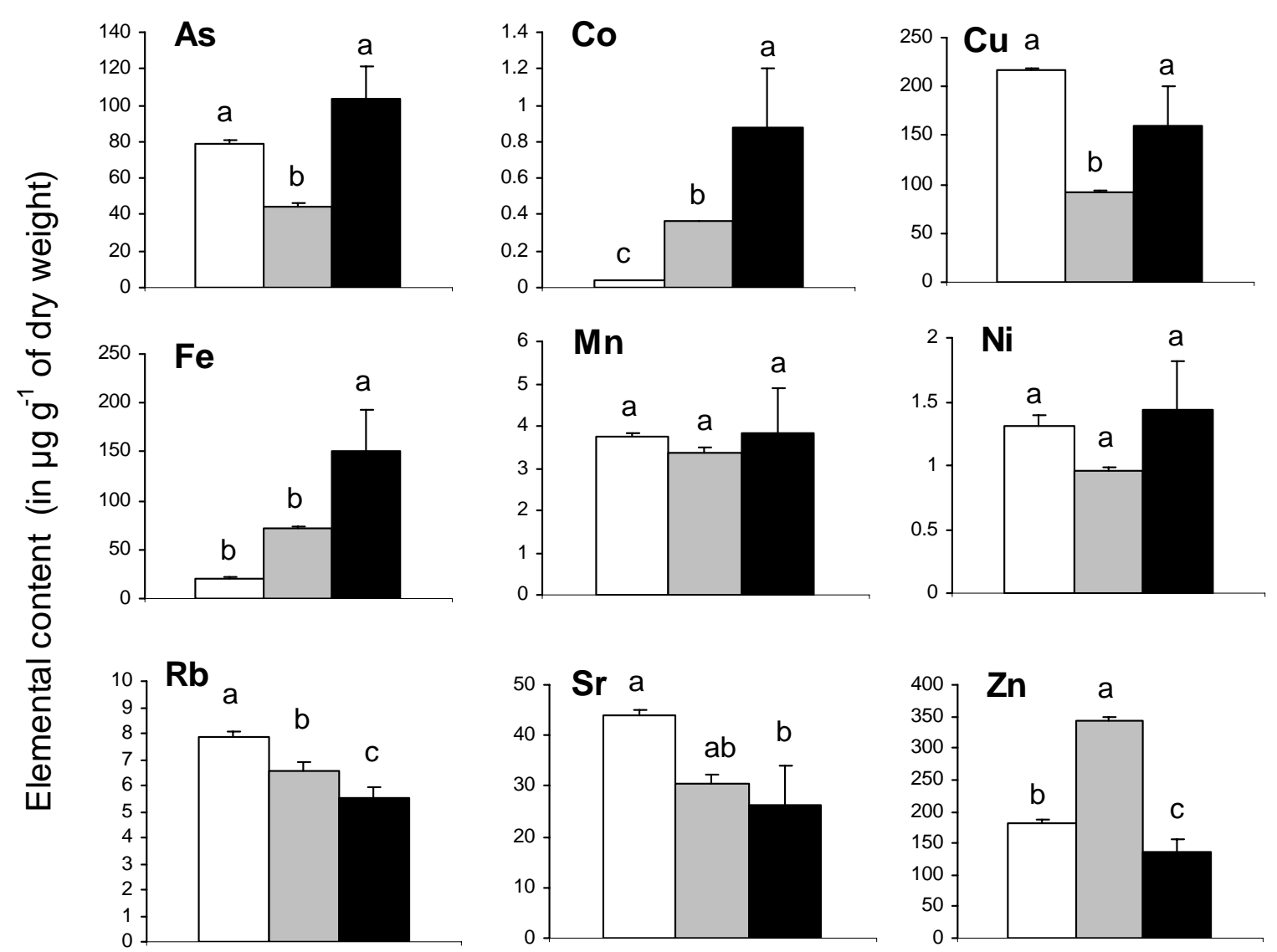

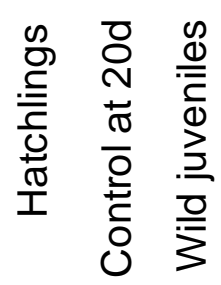
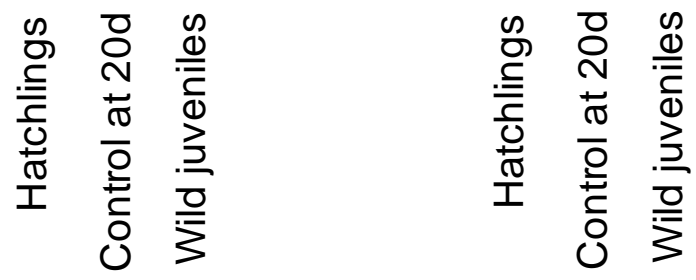

Figure 2. Minor essential elements in Octopus vulgaris. Comparison of the mean and standard deviation in content of $\mathrm{As}, \mathrm{Co}, \mathrm{Cu}, \mathrm{Fe}, \mathrm{Mn}, \mathrm{Ni}, \mathrm{Rb}, \mathrm{Sr}$ and $\mathrm{Zn}$ of hatchlings, reared individuals 20 days old and wild juveniles. Bars with the same letters are not significantly different $(P>0.05)$. Details as in Figure 1. 


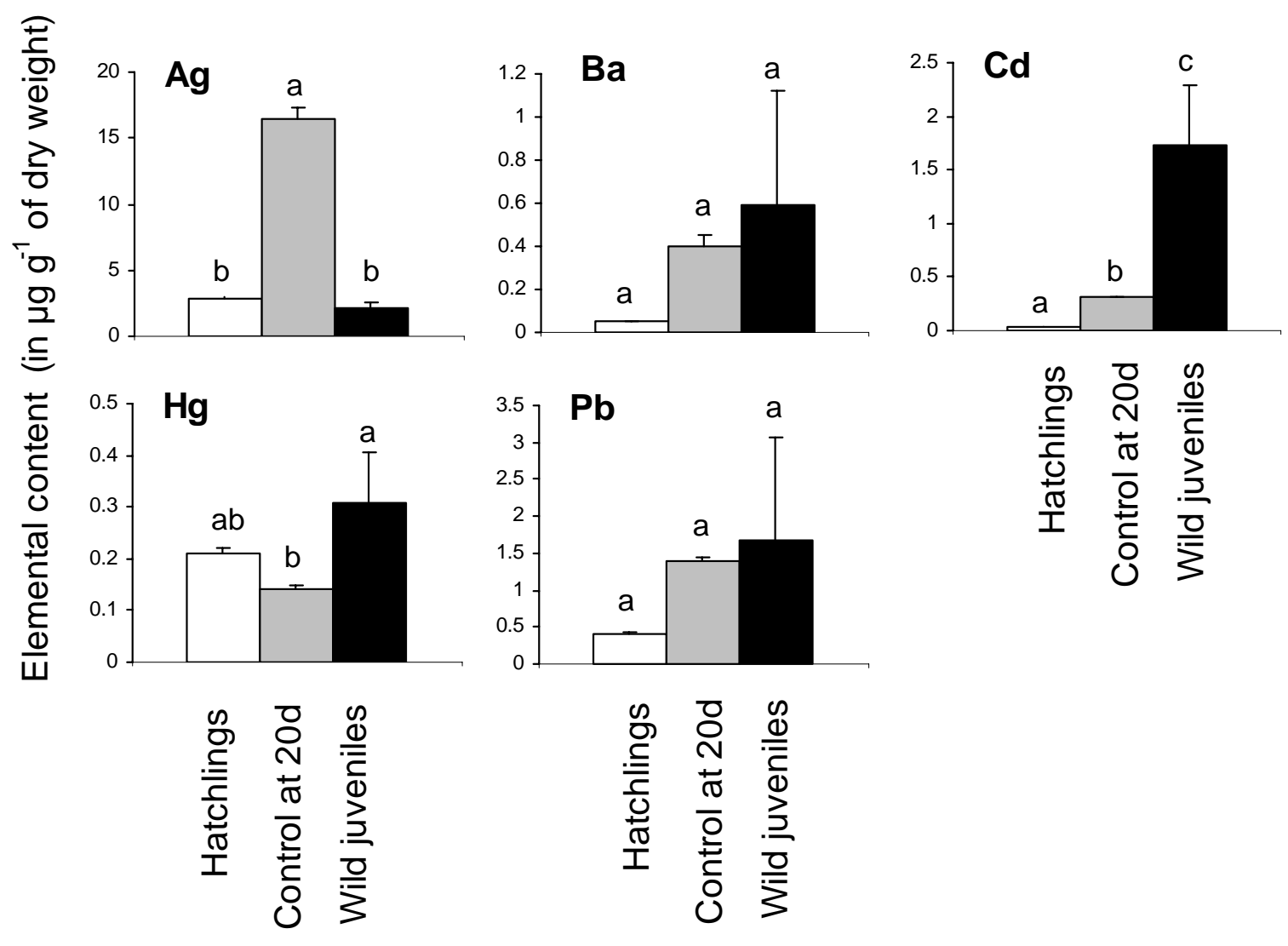

Figure 3. Non-essential elements in Octopus vulgaris. Comparison of the mean and standard deviation in content of $\mathrm{Ag}, \mathrm{Ba}, \mathrm{Cd}, \mathrm{Hg}$ and $\mathrm{Pb}$ of hatchlings, reared individuals 20 days old and wild juveniles. Bars with the same letters are not significantly different $(P>0.05)$. Details as in Figure 1. 